695 . $M / 6$

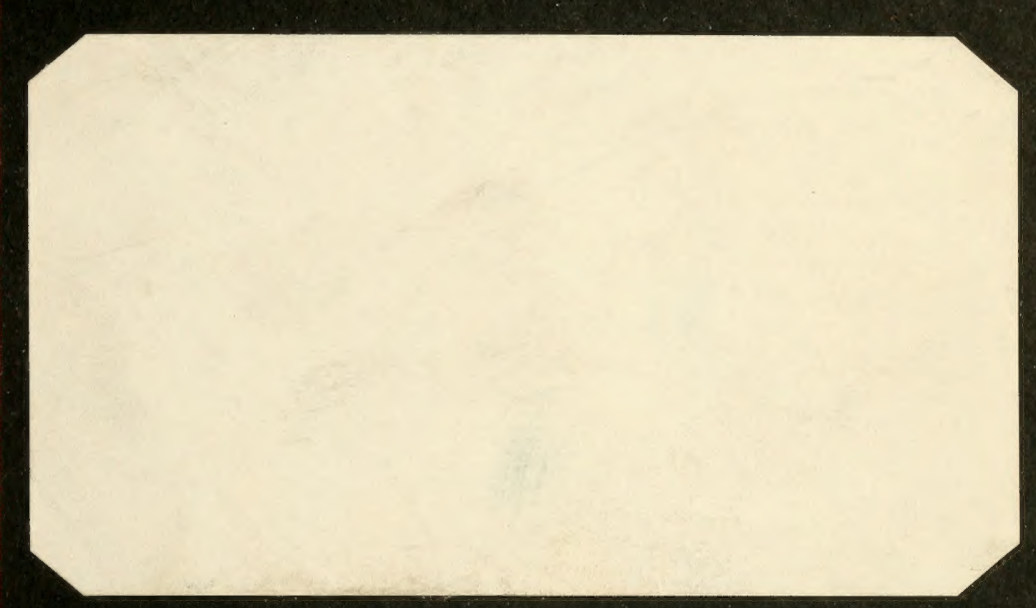




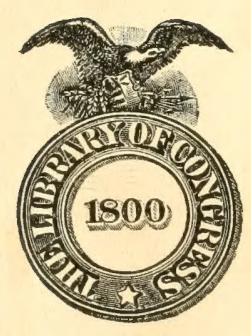



U. S. DEPARTMENT OF AGRICULTURE.

OFFICE OF EXPERIMENT STATIONS-BULLETIN NO. 103.

A. C. TRUE, Director.

\section{The Etolition of Reapisg Mlochises.}

$\mathrm{BY}$

MERRITT FINLEY MILLER,

Bachelor of Science in Agriculture of Ohio State Universily.

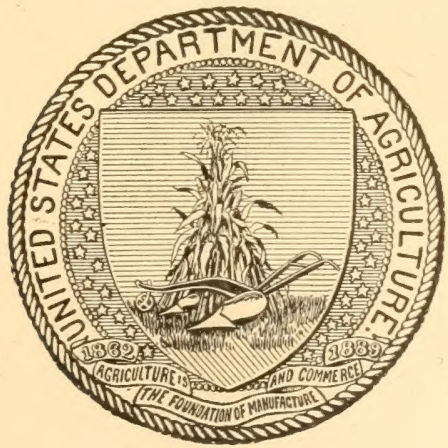

WASHINGTON :

GOVERNMENT PRINTING OFFICE.

1902 . 


\section{5 \\ M 6}

\section{OFFICE OF EXPERIMENT STATIONS.}

A. C. True, Ph. D.-Director.

E. W. Allen, Ph. D.-Assistant Director and Editor of Experiment Station Record.

W. H. Beat, B. A., M. E.-Editor of Experiment Station Work and Miscellaneous Publications:

$$
\text { EDITORIAL DEPARTMENTS. }
$$

E. W. Allen and H. W. LAwson-Chemistry, Dairy Farming, and Dairying.

W. H. BeAL-Meteorology, Fertilizers and Soils (including methods of analysis), and Agricultural Engineering.

Walter H. Evans, Ph. D.-Botany and Diseases of Plants.

C. F. Langworthy, Ph. D.-Foods and Animal Production.

J. I. Schulte-Field Crops.

E. V. Wilcox, Ph. D.-Entomology and Veterinary Science.

C. B. Бмнтн-Horticulture.

D. J. Crosby-Agricultural Institutions.

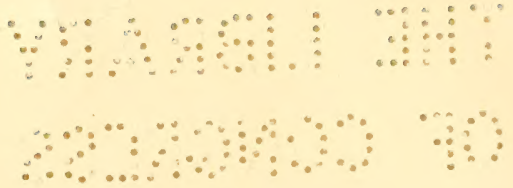




\section{LETTER OF TRANSMITTAL.}

\section{U. S. Department of Agriculture, OfFICE OF EXPERIMENT STATIONS, Washington, D. C., January 1, 1902.}

SIR: I have the honor to transmit herewith, and to recommend for publication as a bulletin of this Office, an article on the evolution of reaping machines, prepared under the general supervision of Thomas F. Hunt, dean and professor of agriculture, College of Agriculture and Domestic Science, Ohio State University, by M. F. Miller, when a candidate for the degree of bachelor of science in that college. The article summarizes the history of the various stages in the development of reaping machines in so satisfactory a manner that it is deemed worthy of publication by the Department as a useful contribution to information on the important subject of farm machinery. It has not been attempted in this summary to refer to all inventions in connection with reaping machines, but, as a rule, only those are considered which have marked some important advance in the development of the perfected modern machine. A few of the more important sources of information drawn upon in the preparation of the article are referred to in footnotes; a more complete list of authorities consulted will be found at the end of the bulletin (p. 42).

Respectfully,

A. C. True,

Director.

Hon. JAMes Wilson, Secretary of Agriculture. 



\section{CONTENTS.}

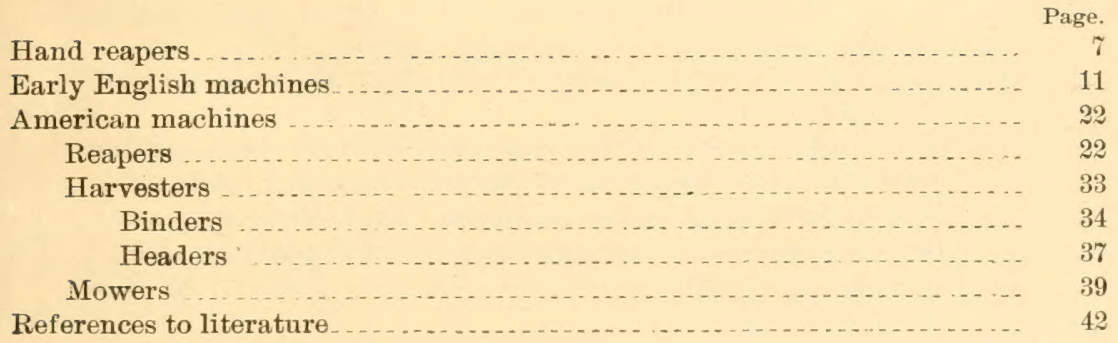




\section{ILLUSTRATIONS.}

PLATES.

Plate I. Fig. 1, early cradle scythe; fig. 2, American cradle scythe; fig. 3, the Gallic header (A. D. 70)

Page.

II. Fig. 1, forms of early cutters (circular motion); fig. 2, forms of early cutters (rectilinear motion) .......................

III. Fig. 1, Smith's reaping machine (1814); fig. 2, Ogle's reaping machine (1822); fig. 3, Bell's reaping machine (1828)

IV. Fig. 1, Hussey`s reaping machine (1833); fig. 2, McCormick's reaping machine (1834)

V. Fig. 1, Hussey's early cutting apparatus; fig. 2, Hussey's cutting apparatus after improvement patented August 7, 1847; fig. 3, Mc Cormick's early cutting apparatus; fig. 4, McCormick's cutting apparatus after improvement patented January 31, 1845 ...

VI. Fig. 1, an early form of self-rake (the New Yorker); fig. 2, a modern self-rake

VII. Fig. 1, the Marsh harvester (1866) ; fig. 2, a successful wire binderLocke's (1873)

VIII. Fig. 1, a modern header; fig. 2, the combined harvester and thresher-

IX. Fig. 1, Ketchum's mower (1847); fig. 2, Lewis Miller's mower (1858)

TEXT FIGURE.

FIc. 1. Different forms of sickles and scythes 


\section{THE ETOLUTIOX OF RE.IPING IIACHINES.}

\section{HAND REAPERS.}

Agricultural machinery is a most important factor in the world's progeres, and one which has shown a marked development in recent years. In no colass of agrieultural implements has there been a more maked development than in that for peaping erain. This development has taken centuries, not because of such a great number of stages, but because of the time in which development was almost wholly wanting-a time extending through renturies when the sickle reigned supreme.

The process of reaping is older than written history. Among the remains of the later stome perios in freat Britain and on the Continent are found implements of llint resembling a rude form of sirkle or reaping hook, while bronze sickles oreur quite frepuently amoms the remains of the early European inhahitants. Our earliest records give areounts of reaping, which was in most cases calred on by means of implements fesembling our morlerm sickle in form, hut of erukle construction. These atrliest records are from Egyptian history. In that favored land, watreed and fertilized hy the river Nile, we see the early stages of agricultural development. Here grain was sown, trampled into the loose ground hy the hoofs of animals, and left to grow from the rich soil where so little care was needed to produce a ('rep. It is amomg the early works of this rematkable people that we find the first records of the processicalled reaping. A tomb at Thebes, probably built 1400 or 1500 [3. ( various operations connected with the cultivation and harvesting of grain. After the style of these ancient works of art, the different operations are shown in series in the same painting. Two men are represented with sickle-like implements, contting the grain somewhat below the heads. They stand side by side and apleat to be making the movements simultaneously; behind them a third man, working alone, seems to be gleaning, while others carry the gratin to the oxen, which are tramping it ont. ()ther paintings of this time show two distinct modes of reaping. One was to eut low, a handful at a time, and bind into sheares; the ofher, which may searcely be termed reaping, consisted in pulling up the plants by the roots, the heads afterwards being stripped from the stalls by means of a combl or hackle. 


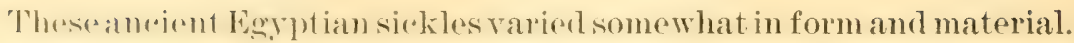
The (atrliest form romsisted of a slighty coured blade fastened at one end to a slraight handle (fig. 1, 11), both iron and bronze being used. Later the forther sickle appeared (fig. 1, d), the form approaching more nearly that of the modern sickle.

The ancirnt chinese and Japanese userl an implement resembling thr sirkle, and almost the samo thing is used by them to-day. The faplatese nserl also another implement for leaping, which they ealled "ani-ani." This cut on the principle of scissors, but was inferior to the reaping hook and was abandoned. It is a remarkable fatet that these two latrere and ancient nations still cling to the reaping hook in harvesting their grain.

The implements of the Jewish people resembled closely those of the
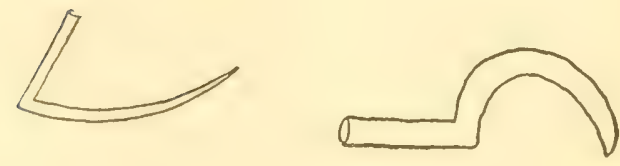

2

6
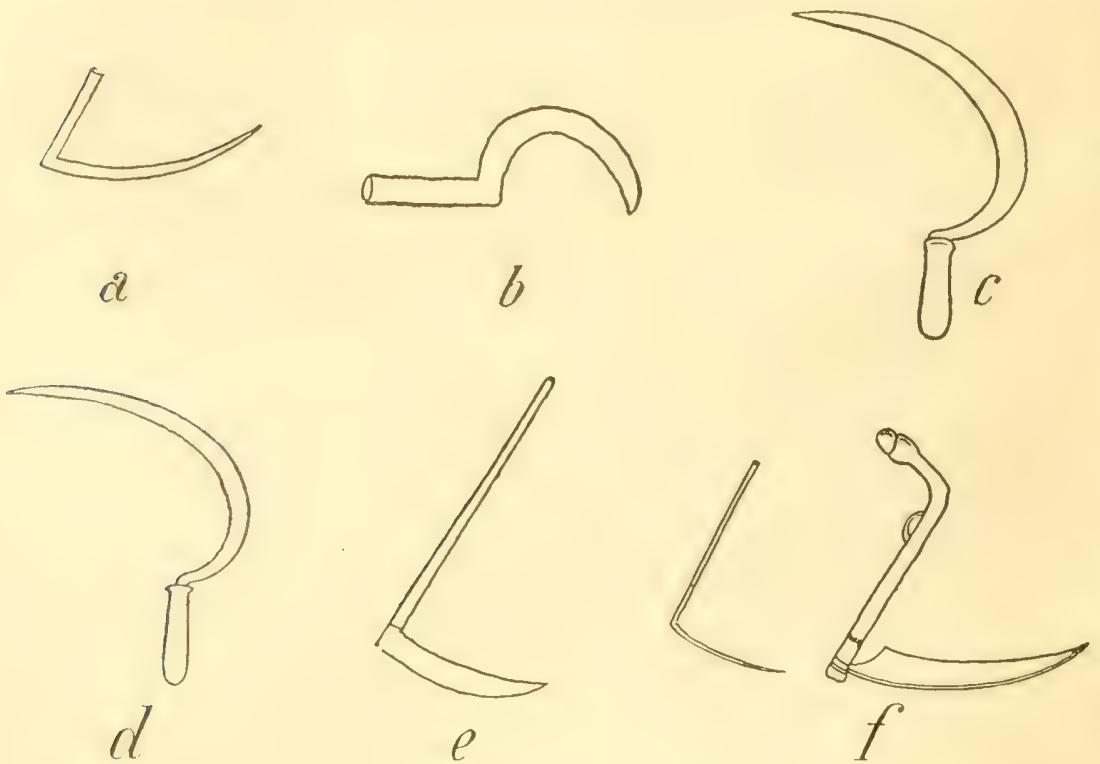

FiG. 1-Different forms of sickles and scythes: $a$, Egyptian sickle; $b$, sickle of the middle ages; $r$, later smooth-edged sickle; $d$, later toothed sickle; $e$, early form of scythe; $f$, Hainault scythe and hook.

Egyptians. 'The sickle was very eommon, and this, together with the reapring foressis, is frequently mentioned in the Bible, for instance: "They reap every one his corn in the field," Job $24: 6$; and again in Revelation 14: 15, we find "Thrust in thy sickle, and reap."

To Greece the art of agriculture was passed down from the Egyptians. The lommans, ion, alded in the development, and considelable adranerment was made in the form of implements during Greek and Roman times. Varro describes three modes of eutting the straw as common in Italy. The first was to cut low with a reaping hook a hamblint at a time; the second, to cut below the heads with a sickle, 
consisting of a curved stick with a toothed blade attached, and the third, to cut at the middle of the straw.

The manner of gathering differed likewise, the grain sometimes heing bound into sheaves, or, when the heads alone were detached, they were either taken directly to the threshing floor or placed in storerooms. Among Roman implements we find besides the ordinary form of sickle and reaping hook a small hooked knife resembling a pruning knife, which was used for reaping. It is at this time also that we find the first records of the seythe being used, and although it is not known exactly when it first appeared, the Romans certainly used it, as ancient Roman drawings show. It was erude in form, consisting of a heavy blade on a long straight handle, and was used more for grass than for grain, the sickle remaining presminently the reaping implement. Pliny distinguished between the sickle and the scythe, although both were at that time called "sickles." The shorter one, which resembled the modern form, he termed the Italian sickle, and the longer one with two handles or hand holds, which corresponded to our present scythe, he called the Gallic sickle.

After Roman times agriculture began to decline anc continued at a very low state for about ten centuries, or almost throughout the Middle Ages. The pasturing of eattle and sheep in such times of st rife and trouble was, of course, preferred to tillage, hecause animals might be concealed or moved; but few will sow without a reasonahle degree of certainty of being able to reap. Some of the operations of tillage were not forgotten, as they were retained by the priests and monks. After about ten centuries agrienlture began to revive, and with it was brought back the extensive use of the sickle and scythe.

Crescenzio in 154 s gives an account of the implements then in use, and among them we find forms of the sickle and seythe as shown hy drawings. From this time on, both are found in very general use throughout different countries, and both have remained as useful implements up to the present time.

It would be impracticable, if not impossible, to trace in detail the various changes of form which these implements have undergone in the development since the earliest times, but some of the more important types should be mentioned.

As already stated, the early Egyptian sickle consisted of a slightly curved blade of iron or bronze, attached to a straight handle, while the toothed form of the implement was a later Egyptian type. Soon a greater bow was given the blade, and it began to look more like the modern form. The smooth sickles were heavier than the serrated forms, and were generally user for cutting near the ground with a chopping motion. The toothed sickle was used to cut the grain nearer the top by means of a drawing motion. As time went on the blade was strengthened by an iron ridge near the back, and finally a steel 
adge was used. With these improvements both the smooth and serrated sickles reached their most perfect form.

The seythe was a later implement than the sickle, and was an evolution from it It forms what might be termed the second class of reaping appliances, the sickle being first and the horse reaper last. As has beren stated, this second rlass mate its angearance about the time of the Roman era. The first forms had straight handles and were very clumsy and heavy, being used only for eutting grass. A Flemish implement known as the Inamate seythe was a form intermediate bet werell the sidele and segthe, and was used for rutting grain. It consisted of a wide blade about 2 feet in length, with a handle a little over half as long. It was held in the right hand with the forefinger in a leather loop, the blade being kept in a horizontal position by a flat, projecting part of the handle against the wrist. (See fig. $1, f$.) The grain was gathered by a hook held in the left hand. This was much more efficient than the sickle, but was surpassed by the later forms of the cradle seythe.

The forms of the seythe varied greatly, particularly in the handle. The blade became lighter as time went on, and the handle passed through various double, forked, and iron forms, to the final erooked wooden pattern. But with this development, a new feature appeared, which transformed the seythe into a practical hand reaper. This was the fastening of fingers to the snath to assist in collecting the grain into bunches or gavels. Among the earliest devices of this kind was one which consisted simply of "two twigs of osier put semicireularly into the holes made in the suath, near the blade, in such a manner that one semieirele intersected the other." This, projecting upward on the snath, helped to carry the grain around the seythe so as to leave it in a bunch. About the same time fingers were introduced-first a single pin inserted in a hole in the snath, later a series of three or four short fingers on a bar which was fastened to the snath in such a way that the fingers extended on a line with the seythe. 'This form generally had a double suath and a blade much longer than the fingers (Pl. I, fig. 1). In using it the operator eut toward the grain, leaving the eut stalks standing in a fairly well-gathered bunch against the standing grain.

With the development of agrialture amomg the Americatu colonists came an improved form of the eradle seythe (Pl. I, fig. 2). Doubtless all the European types had lwen bought orem hy the eolonists, and what is termed the "American cradle" was simply an improvement upon some of these ardier forms. It is impossible to determine just when this implement was invented, but this is of little consequence, as it was doubtless a growth rather than a single invention. It is known to have been in quite common use before the beginning of the nimeteenth century, and was rapidly taking the place of the sickle. Professor lirewer, of Yale, in his history of agriculture in the 

Thited states, written for the Census Report of listo, divides the history into four periods, the second of which extends from the time of the Irelatration of Independence to the introduction of tha rast-irom plow about fifty years later. Of this period he says:

Many other improved implements came into use during this same fifty years, of which the two most important in connection with American grain growing were the American cradle and the fauning mill for cleaning seed after it was thrashed. The sickle was common, thrugh not in miversal use at the time of the American Revolution. It was rarely used when the century closed and had ceased entirely as an implement for cutting other cereals than Indian corn before the close of this period.

These statements fix the introduction of the American cradle as somewhere between 1776 and the close of the century.

The Ameriean rathe wats the culmination of the improvements in hand-leaphing implements which hat bugm angs hefore in the rude stone implements of prehistoric races. Why it should have taken so many centuries to reach its perfect form is a subject for conjecture.

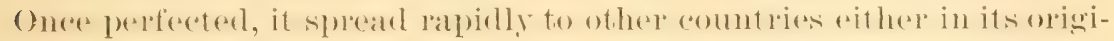
nal form or in a form modified by foreign manufacturers. 'To-day it is still used in various parts of Europe, and even in America where conditions make the use of the reaping machine impracticable.

The sickle still has its place even in the most advanced nations, and it is used almost roclusirely in some of the least dereloperd comtries, especially in the Orient. The scythe also is a necessary implement in the nations most advanced in agricultural methods. But, with the advent of the horse roaper and mower, these crude hand implements ceased fo oreupy any important plase in modern agrieulture.

\section{EARLY ENGLISH MACHINES.}

It is a remarkable fact that the operation of reaping should have been carriest on for centuries with the sickle amel seythe as the only reaping implements. Yot, surh wats the catse, fol almost mothing was done toward construeting a leaping machine until near the close of the eighterenth contury, and almost one-thirel of the nincetenth erontury

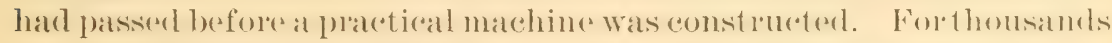
of yeats the sickle hat been the only means of cutting antain, with the exception of the scythe, which came into use in the later centuries. But now a new era was ushered in-an era in which the reaping process was revolutionized and the possibilities of gratin anwing extrodod by making the labol of gathering the grain one of the smallest fatetors connected with the industry. 'There were a few attempts made towad constructing a reaping machine "ven during this long gerion whell the sickle held sway, but they were rude affais and were of little consequence. It is thought, also, that some such machines were in use by the ancients, of which we have no records, but this is only conjecture. 
The first mention in history of a reaping machine is one deseribed by Pliny during the first "antury, as in use in the fields of Gaul. (See PI. I, fig. :3.) It was not a true reaping mathine, but a "header," consisting of a large hollow frame, mounted on 1 wo wheels, and set with teeth along its front edge. These teeth "anght the heads and tore them off, after which they were raked into the box by an attendant. This machine, like all the early forms, was pusherl hy an animal yoked behind it. Palladius gives a similat aceount of the machine, and adds that "the driver can set the teeth high or low, and that a few goings over the fiedds will ceanly reap it if the ground is smooth." $\Lambda$ s this mention by Pallatius was made in the fourth century, it is probathe that some form of the machine was in use for many years, but nothing very practical came of it, and it seems to have been forgotten for centuries.

But now we come to the age when inventors began turning their attention 10 machines to lighten the lahor of harvesting, to a time when competition was becoming more fierce, labor more costly, and any saving of time a gain to civilization. The first of these reaping machines was after the plan of the ancient header of taul. A man by the name of ('apel Lofit, of Britain, first suggested the idea of a reaping machine, in 1785, probably as a result of the proposal made in 17so, by the society of Arts, for a premium to be given the author of such an invention. 'This machine was probably never built, but existed only in the model or on paper. Little is known of its construction, and it is of interest only as being the first one suggested. In 17sf or 1787 a makhine was construeted hy William Pitt, of Pendeford, England, which was in reality a header, but which was construeted on a principle somewhat different from the Lofft and Gallic mathines, although doubtless suggested by them. Instead of a row of fixed teeth, a cylinder fitted with rows of comb-like teeth was placed horizontally on the front part of the frame and made to revolve by the power transmitted to it from the wheels. As it revolved, the inclined teeth aught the heads and carried them over the eylinder into the box of the machine. The animal was of course attached behind, which was a dhatacteristic method of hitehing in these early forms, since it was necessary that the grain should not be trodden upon, and no one had as yet thought of the side cut.

In 1793, two men by the name of Cartright each invented a machine for mowing and reaping, but deseriptions of them are wanting. The reverse is the case with a machine invented in 1799, the name of the inventer being wanting but the deseription being known. It is described as cutting the grain close to the ground by a number of knives on a wheel that revolved upon a circular piece of sheet iron, to which were riveted a number of steel, points. 'These points were pushed into the standing grain and served not only to hold it but aceded also ats ome-half of a pair of sheats (the revolving knives being the other) by which cutting was effereted. The gratu, falling upon a platform, was swept by a rod, fixed to the axle of the wheel, off the 


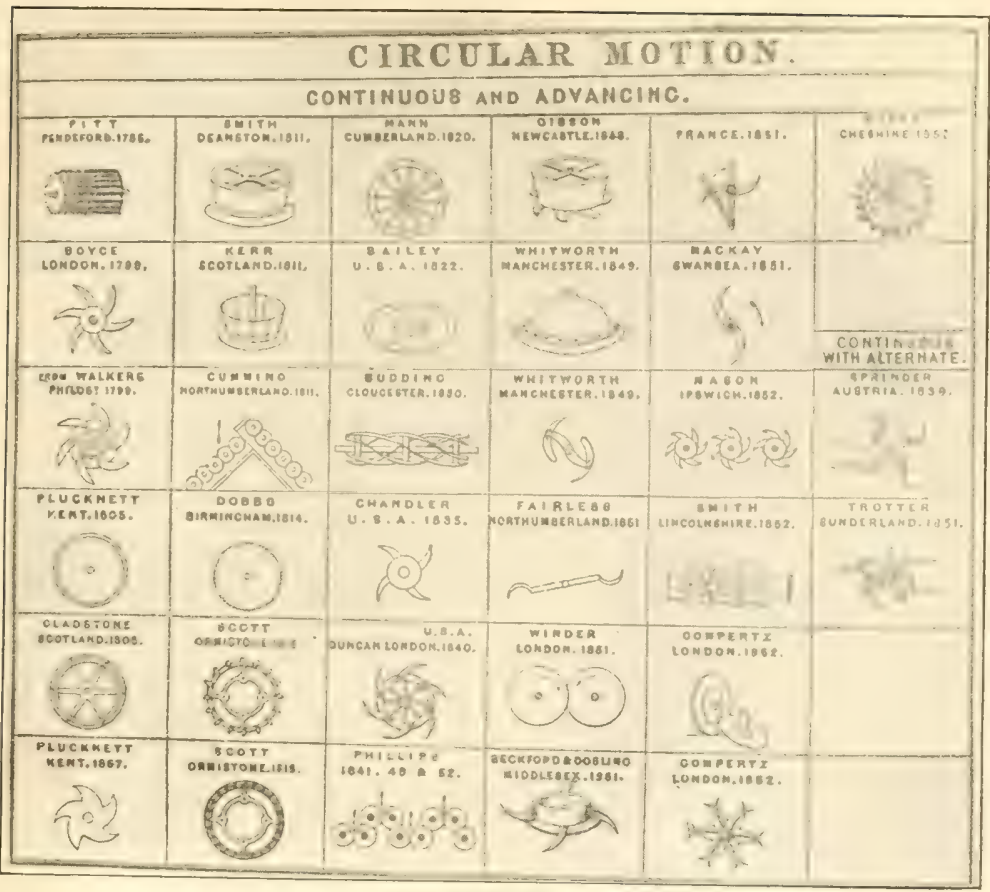

Fig. 1.-Forms of EARLy CutTers iCiRcular Motion!.

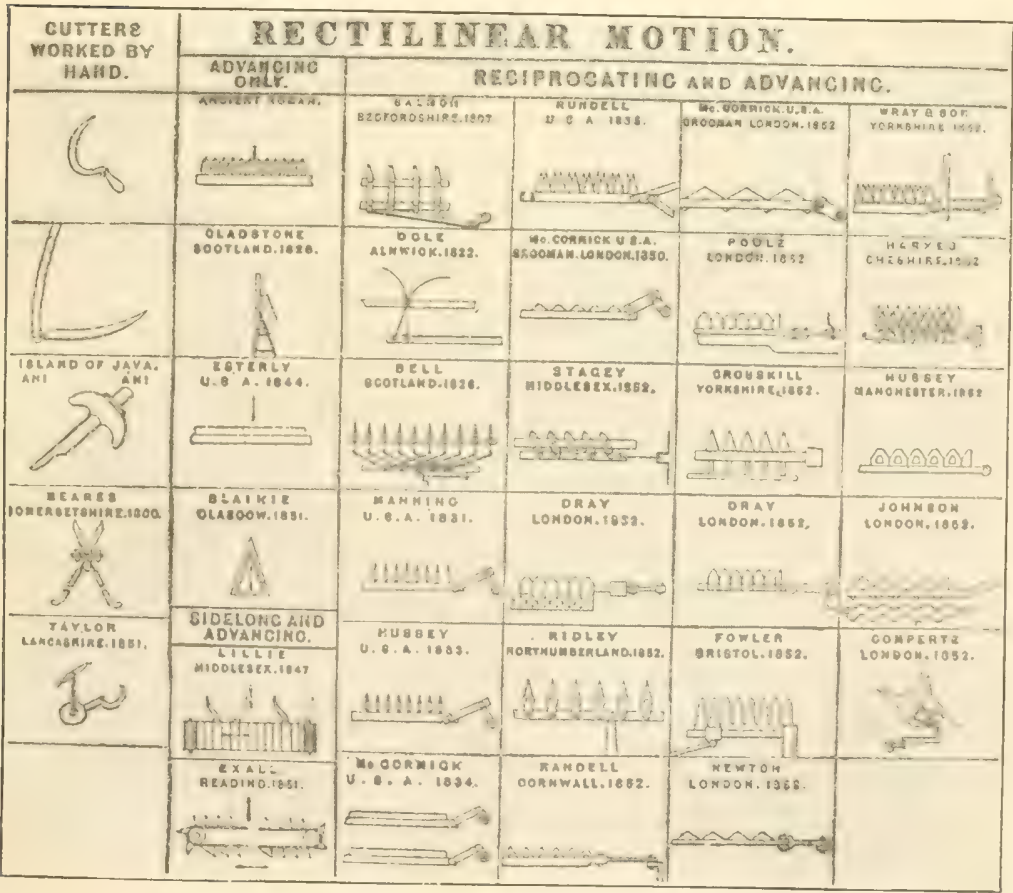

FIG. 2.-Forms OF EARLY CUTTERS (RECTILINEAR MOTION). 

platform and laid in the form of a sheaf out of the way of the next course of the machine. Nothing more is heard of the machine, however, and if it ever advanced beyond the model it was probably a failure. It possessed some valuable features, however, if properly constructed, and seemed far in advanee of the ideas of that time. The revolving-knife principle which it embraced was a favorite among the early inventors, after the headers had proved to be failures. The header's formed the first type of cutters or severers, the revolving knife the second, and the reciprocating knife the third and most suceessful type. The revolving principle was naturally suggested by the motion of the sickle or scythe, linked with the revolving of a wheel.

A man by the name of Walker made at two-horse machine in 1799 , but it was inefficient and was soon forgotten.

The first machine of importance working on the revolving-knife plan was that of Joseph Boyce, of London, also built in 17!9!, which was the first English machine patented. It had a rertical shaft, to which were fastened a number of blades. This shaft was made to revolve by power transmitted from the wheels on which the machine was mounted. It had no contrivance for gathering the grain to the knives or for laying the cut grain in a swath or in gavels. The next year a man by the name of Mears attempted to aropt shears as a eutting apparatus on a machine which he worked by hand, but it was not successful, since neither the shearing apparatus nor the mode of applying the power was practical. During the next four years nothing of importance appeared, although a few attempts were made both in Europe and in the United States. Two machines by an anonymous Frenchman are mentioned, but details concerning them are meager. We only know that "one was on the rectilinear motion, advancing only, and the other on the circular motion, continuous and advaneing." A few scattering inventions were made in the I'nited States in the early part of the century, but they were unimportant.

The next important invention was by Plucknet, of Deptford, in the year 1805 . It consisted merely of a rotating circular plate, toothed at the edges, entirely destitute of any gathering apparatus, so that, if it eut at all, it would leave the grain in a tangled mass. It gained no reputation and was speedily abandoned.

The following year Gladstone invented a machine with a circular revolving cutter having a smooth edge. It was supported on a carriage frame with two main wheels and a pair of long shafts projecting forward and to one side, so that the horse walked beside the grain, pulling the machine, this being the first machine to be drawn. The circular eutter was overlapped by a sort of shield, armed with pointed projections which served to gather the grain and hold it until eut. It had outside and inside dividers, and a complicated gathering apparatus was used, consisting of a platform above the rotating knife, on 
which the gratin fell and from which it was swept by a ralke, leaving it in small bunches. It was very ingenious, but failed on alceount of the complicated gatherer.

In 1 sis Mr. Salmom, of Woburn, brought ont a makdine containing some new features, the most important of which was the eutter used. This andsisted of a low of vibrating knives adeng over stationary blates, and was the first vibrating eutter. It, was the first to combine the reciprocating and advancing motion, and was the first hint at the thipl alass of cotters, or those with a receiprocating knife. The plan of delivery was somewhat in alvance of the day, consisting of a vertically working rake, driven by a rank in the rear of the matehine. By this means the grain was raked from the platform, which was placed just behind the eutter. The machine promised much, but owing to certain defects it was a failure and was abandoned. This same year loluckuet hrought out an imperement upon his machine of 1sto, including a side draft and a self-elelivery apparatus. IT to this time mone of the mathines had approached perfection, and few hatd bees operated beyond a mere trial. Litfle attention was paid to them by partical farmer's, and they eonstituted but a small factor in agricultural operations.

During the next thees or four yeats nothing was acemplished worthy of mention; but in 1811 a Mr. Smith, of Deanston, built a mathine (IP. III, fig. 1) which he kept improving until listt, when it performerl its work hetter than any which hand appeared up to that time. It was designed primarily as a mowing machine. It had the rotating-entfer principle, atnd consisted of a frame-work mounted upon two wheels, bearing an inverted conical drum with a projecting eircular knife at its lower and smaller end. This drum was made to revolve by motion transmitted to it by a system of cogs connected with the wheols, thus severing the grain and bearing it to one side into a swath. Two small wheels beneath the drum kept the knife at a proper distance from the ground, and a contrivance was added by which this distanes eould be increatsed or decereatsed. It followed the old plan of having the horses hitched behind the machine.

About this time a man by the name of Kerr brought out a machine working on the same principle, and puite at dispute arose between the two men as to who was the real inventor. From the circumstances of the case it seems probatble that the idea was original with both ment as has happened many times in important inventions. Both machines became popular in sirotland, and rereiverl prizes from the Highland and Dalkeith societies.

In 1811 two other machines were brought out, both by Northumbrians, John ('ommon and Domahl cumming. The latter's machine was patented and was a novel affair. The eutter "consisted oi a

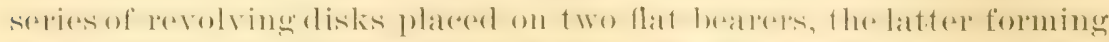
an angle whose point faced the grain. As the mathine moved for- 

ward the grain was ent between the revolving disks. A series of 'hold fasts" projected hefore the cutters to lead the grain up to them. The grain was gathered hy revolving ranes or drums and carried off to each sidle of the machine by endless webs." This machine had some pretensions to efficiency, and foreshadowed some of the appliances of modern machines, but it was too complicated and visionary to be practical, and was som forgotten. Common's first matehine was of little value, but the next year he brought out another, with an endless web on two roller's which gave a side delivery, while his knife had somer resemblance to the famous II ussey pattern of the Western Continent. It was not patented, and was soon forgotten.

The next machine which makte its appearance was one invented by James Doblos in 1814. Doblos was a dramatist, and he worked the machine on the stage npon a small field artifieially planted with wheat. The eutter was eircular with a toothed edge. 'The body of the mathine resembles a wherelbatrow, and was pushed forward in the same way, the drive wheel being plated hetween the handles. It hat quite a complicated system of rollers and dividers to leath the gratin to the cutter, but it was not pratedical, and wat probably remembered only because of the manner in which it was introduced.

The next year (1815) a man by the name of Scott, of Ormiston, produced a machine with a rotating entter eonsist ing of a wherel carrying 16: small-toothed sickles and having projecting prongs in front like

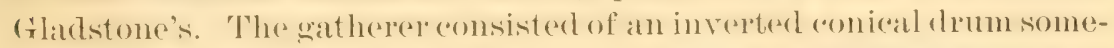
thing like smith's, but with :t jointed prongs projerting from it to act as collectors or rakes in carrying the grain from the cutter to the ground. It had several minor contrivances, but did not, work beyomel a trial.

Nothing further of importance came out, until 1.520), when Mann, of Roby, constructed his molel of a reaping machine. 'This attracted much attention, but the full-sized machine was not constructed until 162a, and, when it did appeate, it wats so complicaled that suecess wass doubtful. He continued to work on the machine, however, until 15:3:, at which time it could be described ats follows: A wheeled frame bearing a polygonal revolving rotter, with a series of revolving rakes for carrying the grain to the swath, and an apparatus for eleaning the rakes. The machine was drawn, and the line of draft, although applied in front, was parallel to the line of motion. The special feature was the twelve-sided cutter, which was axpected to bo more efficient than a cireular onr. It did not come up to expectation, however, and although used to some extent in the field, it never came into general use.

We now come to one of the most noted inventions in reapers, that of Ilenry ()gle, a sehoolmaster of Remington, whose machine (Pl. III, fig. 2) (ame out in $1 \mathrm{~s}^{2} \mathrm{z}$. ()gle was a genius of high order and well 
deserves the honor bestowed upon him. The mathine itself never became popular, but the principle of the cutter together with the reel which he comstructerl is fomel incorporated in every successful reatper since that time. IIe constructed a model of a machine in 1832, but not being a workman himself, he submitted the making of a fullsized matehine to Thomas and Joseph Brown, of Alnwick, England, who afterwards helped him in his design. Hence the mathine is sometimes spoken of as the Ogle and Brown machine. It resembled the skefetom of a capt with wheels and shafts, the horse walking allead beside the standing grain and the "utting apparatus extending to the right side. This cutter consisted of a frame whose front har was of iron armad with rows of teeth 3 inches long projecting forward. I)irolly under these lay the cutter, a straight-edged knife. There was a real resembling the modern form, which pushed the grain backward onto a platform situated behind the cutter. 'This platform if hinered rould be used as a dropper; if fixed, the grain could be raked off in gavels. In the words of Mr. ()gle this platform when hinged "is lifted till as much corn is collected as will make a sheaf and let fall hy a lever upon the frame, when the corn slicles off, when it is a littl raised again. It was found, howerer, to answer hetter when it was put off with a man and a fork towarl the horses, as it is easier bound and leaves the stubble clear for the horse to go upon." From the position of the lever a seat was evidently provided for the operator.

Here, then, we have the foreshadowing of the future reaper-the reciprocating knife over stationary fingers, the reel, the platform, and divirlers. It was drawn from the front and side and was borne on two wheels, as are all modern machines. To be sure, the dividers and platform harl been used before, while Salmon had made a kind of reciprocating knifo in 1 sor ; yet the latter was very unlike this, acting more on the principle of the scissors. Ogle should be given the eredit for the first reciprocating knife combined with stationary fingers, together with a very hippy combination of other lasting features of the reaper; and while the machine never became a great success, owing in a great measure to the disfavor in which reaping machines were held by laborers and to the threats made upon the manufarturer, yet it was the embryo of the modern reaper and holds a prominent place in the development of these machines.

$\mathrm{Up}_{\mathrm{p}}$ to this time no machine had been in any great degree suceessful in the field. To be sure, some of them, such as smith's and Kerr's, had bern used to some extent, but the erreater number had not survived a few tests. We come now to a machine which was brought into use in considerable numbers and which was used for some time in the fields of England and scotland, some even being sent to this country. It was invented by Patrick Bell, of Carmyllie, Forfarshire, in 1826 and put in the field in the following year. Bell was a minis- 
ter, but, being quite familiar with agricultural operations and having an ingenious turn of mind, he applied himself to the task of inventing a reaper, which he saw was badly needed at that time. After much eomsideration he (onstrueded an appatatus which he thought would do the work, making his first tests on an artificial field of oats in his workshop. After ahout two year's experimenting he bought out what has since been known as the Bell reaper. (Pl. III, fig. 3.) It consisted of a wooden frame monnted on wheels, with a pole extending backward, to which the horses were attached. The eutting apparatus wats on a shearing or clipping principle and consisted of thirteen stat tionary blades about 15 inches long and about 4 inches wide at the wider or base end, above which were placed twelve movable blates of about the same size, fastened on pivots so as to be moved back and forth over the stationary ones below, thus giving a motion like to that of so many pairs of shears. The power was communicated to the morable blades by conneceting their rear ends with a sliding bar, made to move by an oscillating rod connected with a worm flange on a revolving shaft. I canvas moring on rollers and sloping to the cutters carried the eut grain to ons side, where it was left in a continuous, even swath. The mathine wats also provided with dividers and with a reel much like the modern forms.

This machine, although built on the wrong principle to ever become a great success, was used for many years in various parts of England, or until the introduction of the better machines springing from the inventions of Hussey and Hecormick, the two Americans whose machines were made the basis of the wonderful development in harvesting implements which took place within the next fifty years. With the introduction of these American machines there entered a foreign element into English invention, and from this time on the machines of importance were various improvements upon three types-Bell's, IIussey's, and Mccormick's. Of course, there were sundry other inventions which did not include the principles of these machines, but they were of litte consequence in the real development of the reaper. Up to 1831 there had been 2 French, 1 German, 33 English, and 2: American inventions recorded, with a few unimportant attempts in this line from various other sources; but to follow any except the machines related to the three mentioned would be not only impracticable but useless.

Before considering those machines, which combine both English and American elements, it would be well to notice what should be conceded to English inventors in this interesting development; and although American inventors from this point take almost the entire burden, it is undonbtedly true that they receiver their first ideas from their brothers across the Atlantic.

For the reciprocating knife orer stationary fingers and for the revolving wheel we are undoubtedly indebted to Ifemry Ogle, whose 8910-No. 103-02_-2 
unique marhine contained so many clements of the modern reaper. For the platform on which the grain falls we must look first to Glarlstone, who in 1806 used such a contrivance on his machine. ${ }^{1}$ The machine fated, but the principle of the plat form has survivet. As to a grain board or dividere it is somewhat uncertain who should be given the eredit of atrancing this idea. We find that Dobbs, in ls14, had a " "omplicaton process of roller's and divider's to lead the cornt to the cutter," while Gladstone's machine, with its stationary fingers above the revolving knife, and salmon's with its elipping eutter, undoulotedly had something of this sort. (tadstome's machine contains the first hint toward a self-rake, while Salmon repeated it in a different form. Cummings' machine of 1811 rontained a reel. Ogle must be credited with the first droprer in 18:2, and Gladstone with the first side-draft machine in $\mathbf{1 8 0 6 .}$

IV must credit the English, then, with the first reciprocating entter and divider, the platiorm, the reel, and side-draft features, and with the first forms of the dropper and self-rake; but it is to Ameriean ingenuity that is mainly due the rapid perfection of the practically sucessful grain harvester. 'Thus far the English came alone, but from that point their influence began 10 wane and American genius completed the remaining chapters of the development.

of the machines "in which both English and Ameriean prineiples were blended there are some that are of special importance, but few that aid us materially in tracing the true development of the reaper.

'The Ifuscy machine, introluced into England neal the middle of the past century, consisterl of a low frame mounted on two wheels, the latree being the drive wherel which tramsmitted the motion to a vibrating bar, bearing pointer blates or sections working through slots in iron fingers projerefing forwarl on the front of the eutter bar. Behind the cutter wats phated at platform to receive the cut grain, from which it was raked by a man riding on the machine. The machine was exeedingly simple, and was without reel or any complicated apparatus.

The HeCormick machine, introduced about the same time as the Inussey, was somewhat more complicated, but hat the same principle of a vibrating knife, exerpting that in this case the knife hat a serrated edge with only a way outline instead of pointed sections as in Ilussey's. The fingers also differed somewhat from the Ifussey type, and a reed was athled to make the entter more effective, hut no plater was provided on the machine for the raker, who was compelled to wall. Both machines were dratwn, the horses being in front of the machine and beside the standing grain.

\footnotetext{
'Scientific American, July 5, 1896.

${ }^{2}$ Journal of Agriculture, Edinburgh and London, 1853-55, p. 617.

The descriptions of these English-American mathines are taken from Jacob Wilson's Essay on Reaping Mitchines. published in Transactions of the Highland and Agricultural Society of Scotland, 1863-65, p. 123.
} 
With these hrief descriptions it is possible to slance with more intelligence at some of the modifieations brought out hy the English inventors. It should be noted here that many of the machines constructed at this time rombined hoth grass cutting and roaping appliances, and were used for both mowing and reaping. 'Thus the mower' was born in combination with the reaper, and it was only in later forms that it became a separate machine.

It was at the great exhibition of 1851 where such a golden opportunity was given for the display of inventions that a widespread interest became manifest in regard to reaping machinery. 'This was occasioned rhiefly by the alpleatrance of the Ifussey and McCommick matehines which were entereed in (e)mpletition at this time. In adelition to these, a matehine was cont ributed hy a Mr. Galrett which, however, was the invention of a man hy the name of 'Tolemache. It possessed the advantage of a side delivery, and the horses were yoked one before the other. Numerous models were exhibited but these were the three of importance.

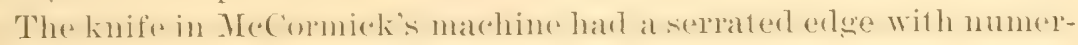
ous obtuse blades riveted into the bar', forming very obtuse angles, so that it acted as a saw, requiring the aid of a reel to hold the grain against it. Hussey's, ou the other hand, had pointed knives which formed very acute angles with the guards, and the cutting was more in the nature of clipping or chopping. It was more likely to choke than McCormick's, and one of the chief objections to it was that it required too fast a pace of the horses to keep it cutting well. Garrett's was inferior to both these machines, and in the trial MeCormick

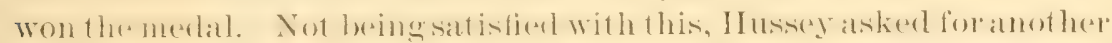

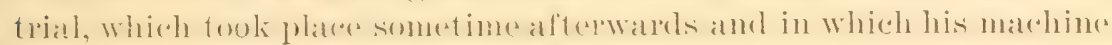
carried off the honors over McColmick's.

Hussey's machine for some time before this exhibition had been manufactured by Dray \& Co., of London, and was called Dray's Hussey, while in 1550 Richard Brooman took out an English patent for MeCormick's machine. During the fifteen years following this exhibition, the progress in invention was marvelous both in the United States and in England.

For purposes of discussion these English machines may be divided into two classes: (1) Those having a mechanical delivery, and (2) those having a manual delivery. In the first class, Crosskill's improvemerit of Bell's machine in 1852 was one of the most important. 'The improvement consisted in the substitution of McCormick's serrated, vibrating knife in place of the scissors form of cutter and in substituting for the revolving canvas a series of endless bands of vulcanized rubber, fitted with projecting pieces of wood. Burgess and Liey matran improvement on the MeComick ly plateing on it a swath delivery apparatus, in the form of a series of Arehimedian serews, which laid the grain in an even swath. It also contained a few minor 
imporevements surh as a levolving cone which acedol ats a dividere, and the height of cut could be regulated while the machine was in

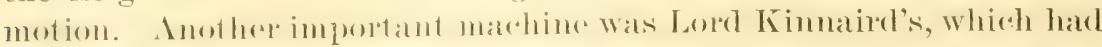

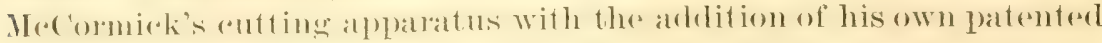
delivery apparatus, consisting of endless bands over a smooth surface, being similar to that of Bell's. The horses walked at the side one before the other, the rear one being hitched to the shafts. It was a simple machine of light draft.

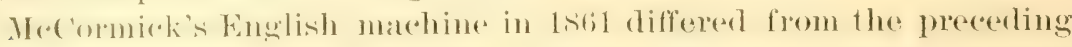
in delivering the grain in gavels rather than in the swath. It was virtually the American self-rake, which will be described in the next chapter and which had by this time berome very eommon in Ameriea. It hat a series of revolving vanes, one of which was made to sweep the grain from the platform out of the way of the next round. It was manufactured by Burgess and Key.

A machine introduced by sammelson was similar to the Mecolmick

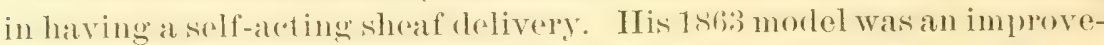
ment over the one of the vear hefore, having four (formerly six) rakes attacherl to an 11 right shaft in such a mannel as to arlmit of a free, asermoling, descending, and horizontal motion. Two of these rakes were dommies, while the of here two hoth gatheresl the grain and raked it from the platform, which was quadrant shaped, so that the grain was left to one side as it was by Mecormirek's malehine. The height of the cut was easily regulated.

In lisfz Kemp, Murray, and Nicholson introduced a machine in whirh a self-delivery aplatatus was applied to an "improved Ifussey." If consisted of a self-alcting tipping platform and a revolving reel with four arms, one of which was longer than the others. At the time when the long arms came in contaret with the grain, the tipping boarl fell, leaving a well-formerl sheaf at resular intervals. A single attenclant was needed to gruide and control the matehine, and the size of sheaf eould be regulated at will. This ronelules the list of important selfdelivery machines up to 1864 .

Of the manual forms which constitute the second class, the followinc may he mentioned: Pickssey and sims's machine, which was tho patent of .Ir. bartlett and which was quite an important machine of this class. It had two wheels with a guard or castor wheel ahead to prevent the cutter bar from coming in contact with the ground. The cutfer was on the elippine principhe, and was allatehed 10 a vertical vibrating bar allowing a very free motion. 'The grain fell upon a platform with a spring which gave way with a certain weight, thus tipping and dropping the sheaf with the atel of the raker, who sat on the machine. It was really a combination of the manual and self-delivery types.

Gamelnej and Lindsay's implovement of the Jussey was a very populatr machine in scotlaud, and was among the first $o^{\circ}$. the improved 
Ilussey's. The machine had two wheels and at eastor in front. The: gutter bar was hinged and folded, this being the first resord we have of such a bar among English models.

Kemp, Inuray, and Nicholson also made an improved Hussey, the improvement consisting of an increased size both in the driving where and in the off-sicle traveling wheel. The speed of the knife was also increased so as to decrease the pace of the horses. The height of cut could be regulated and a contrivance was attarohed for throwing it in and out of gear. Later improvements were applied to the cutter, in which the finger hal was ribherl or flanged so as to incrase st pength, while the knife har weseived a greater freectom of motion, thus making it less liable to rhoke and eansing a lessening of draft. The grain fell on a platform tipped hy the foot of the raker, who, with the assistance of the rake, could make a very neat gavel. A pole was introduced, which could rise and fall, thus making it easier for the horses than a rigid one.

These are some of the improvements made in Encland on the IIussey marehine up to 186iz. Bureses and Kry also marle at this time a manual delivery which hecame a favorite on small farms. It differed from some of its class in having both traveling wheces as drivers, and in having them in advance of the "utter bar, the castor heing behind it. liesides a tipping platform, it had a conical sorew divirler which revolved inward and was driven by the weight of the grain, thus not only separating the erain, but pushing it toward the raker. It was also used as a grass cutter. Cuthbert, of bedale, also improvert the Hussey, making a very good machine. He increased the size of the drive wheels and suspended the rotter bar by at spring so as to lessen the friction. The speer of the knives was mate less, lut the stroke longer than in the original Inssey. Shafts were used instead of a pole, thus giving steadiness of draft. The height of cut coukl be regulated by tipping the machine.

Jack \& Son, of Maypole, began the manufacture of reapers in 1559, hy improving the IIussey, and suceeceded in making good machines, aithough their improvements were mostly in details. In 1860 IBrigham and Bickerton introduced their "Buckeye," an improvert IIussey with a hinged cutter batr adjustahle to different heights. It hat a light draft and was almost too frat. It was both a grain and gratss cutter with different cutter bars for each operation.

Samuelson's "Patent Eclipse" was a onc-horse machine, simple and light, and with an absence of gearing, the driving wheel communicating its motion directly to the knife by means of a lever pinion.

This concludes most of the important manual delivery machines up to about the year $18(i t$, and enough has been sabl to show the develop)ment of the English machines up to that date, and to make it evident that much of it was due to American inventors.

It may be said that most of the above machines which have the 
elipplug principle (as did most of the II ussey type) eome nudrer the

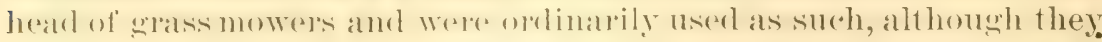
could be used as reapers. 'Thus we see that the mower advanced in great measure, hand in hand with the reaper, so that it is almost impossible to separate the two in the early stages of development. Later we see that the point at which they did diverge was in the con-

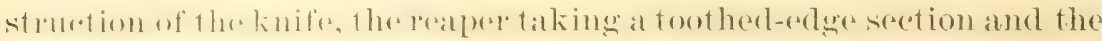

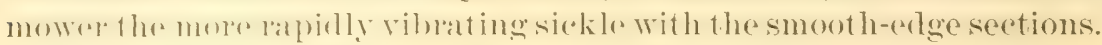
At this point it would be well to pause in noting the development of

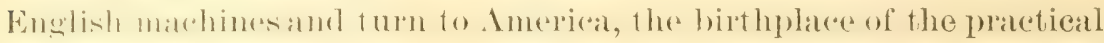
reaper. All the successful English machines at this time were but molilierl forms of the American marhines, so that if is to this rountry that wo mot look for the original patterms and the true development of harvesting machines. The crude English machines of the early part of the century set the American inventor thinking, and in due time he latel the foundation upon which the reaping machines both in America and England have since been constructed. We can here leave the English inventors, conceding to them the origination of the idra, and the foreshatowing of some valuable pronciples, but for the real development we must look to America.

\section{AMERICAN MACHINES.}

'The development of reaping implements has been traeed in broken steps from the mule sickle of the ancient Ferptian through the most important English inventions down to the time when American machines were introduced, by which all inventions were afterwards affected. Attention is now directed to the history of development along this line in America, the birthplace of the successful reaper. In no respect have American inventors exhibited their genius to a

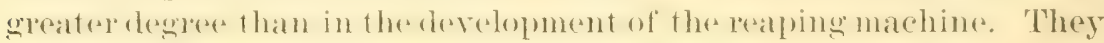
have virtually fashioned their sickles into harvesters. 'They have emancipated 1 he farm laborer from a galling task amel marle possible a wonderful progress in agriculture.

\section{REAPERS.}

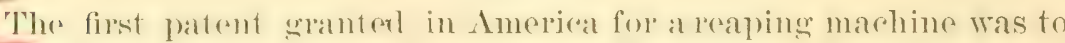
Richard French and T. J. IIawkins of New Jersey, May 17, 1803. This is the earliest record that has been found of an effort to build a reaper, but no reliable description of the machine seems to have been preserved. It had three wheels, one of which entered the standing grain, but other information seems to be lacking. ${ }^{1}$

'l'he earlier American inventions were mostly along the lines of grass cutters, Jout as reapers and mowers were at first so closely related they shomkl be discussed together here. On Dexember t, 1s12,

${ }^{1}$ Eighth Census of the United States, 1860, voltume on agriculture, 1.20. 
Peter Gaillarl, of Lancaster, Pa., was granted a patent for a grasscutting machine, the first of its kind in America, all machines before this time being intended for cutting grain and not grass; thus the idea of mowing grass by horsepower with a machine built solely for that purpose originated in America, although the machine invented hy Smith, of Deanston, in 1811, was designed primarily for cutting glass (see p. 1t). Gaillarl's machine was of little consequence; but on Felnenary 13, 1820, Jeremiah Bailey, also of Pennsylyania, took out a patent for a grass cutter, which gained quite a reputation throughont the country. It was on the revolving cutter plan, and comsisted of a rectangular flame supported hy two latere wherels, one heing inside the frame and acting as a drive wheel, the motion heing transmitted to the rotating ent ter through a series of cons. 'The cutter was shaperl like a low-cerowed hat, the crown being 3 feet 5 inches in diameter and the brim about 1 foot wide. This was of wood, with the exception of the knifo which formed the erlge of the brim. The knife was kept at the propere distane from the gromel by a shoe, so arranged that the distance could be increased or diminisherl at will. The horse walked ahead heside the grass. This was the fims mower that met with the slightest suceess, and it was used to some rextent in practical work. ${ }^{1}$ It was the first to indicate the principle of a flexible bat loy this arlugement for keeping the knife at a uniform distance from the ground.

On May 18, 1s25, a patent was granted to E. Cope and J. Hooper, jr., for a machine which was really only an improvement of the Bailey, as it had the same principle but was simpler.

The next patented invention worthy of notice is one by Samuel Lame, August $s, 1 n 2 x$, for a combined harvester and thresher. It was ingenious, but too complicaterl, and was never userl with suceess. It i: of interest as being the first attempt at this (ombination. Tarious other inventions mate during this early period containerl nothing important and need not be mentioned.

The next machine that should be noticed is one patented by Erastus Ingersoll, May 7, 1s:30. It was a grats cutter of the rotating-eutter type, and, although it nerele attained much distinction, it was a clean invention that should not be forgotten.

The next invention was one of considerable importance, and, although it was built as a reaping machine, its cutting apparatus was an important step in the improrement of both mowers and reapers. The invention was that of William Manning, of New Jersey, patented May 3, 18:31. It had two ground wheels fixed to the same axle, from which a frame extencled, having a har attachment held in place by two arms, and provided with teeth t; or s inches in length, extending forward into the erain. A flat bar of iron lay upon this bar, bearing spear-shaped cutters sharpened on wach of their edges. These were 
about 6 inches long, and cut the grain as it was held by the teeth. ${ }^{1}$ 'This was sulstantially the scalloped sickle, and was Manning's original patent, resembling much the relelurated rutters of Hussey and Ilocormick, which afterwards heeameso smportant. It had a grain divider, the first on record in America.

In $18: 33$ there were three inventions before the IIussey patent was granted, one of which was hy William and Thomas schnebly, and had an intromitent endless aprom for forming gavels. It was not a success.

()bad IIussey, of Baltimore, Mal., patented his world-famous machine 1)(20mber :31, 1833). About this time experiments were in progress with a machine invented by Cyrus II. Mccomick, of Virginia, which, with some later improvements, was also destined to go down in history as ons of the most important machines in the development of reaping machinery. 'This machine is reported to have been first used in the harvest of 1831 , but no patent was taken out until June 21, 1 1s:3.2 These are the two machines which stood out as models for all others that were afterwards successful.

IIussey's machine (Pl. IV, fig. 1) as patented and first constructed was momnted on two wheels to the rear and somewhat to the right of which extended a platform with the cutting apparatus on its front erfere. This platform was at first supported in the rear by a roller. and later a wheel was added at its outer edge. 'The cutter was the unique part of this machine, and consisted of a series of slotted iron fingers through which ribrated a number of triangular knives fixed to a flat bar. The fingers or guards were 7 or 8 inches long, with a slot for admitting the knife and were fixed solidly to the front edge of the platform, extending forward into the gratin. The knife consisteel of a series of triangular plates riveted to a flat iron bar and forming a kind of coarse-toothed saw. One end of this saw was attached to a pitman moved by a cratuk and receiving its motion from the main axle by means of cogs.

M(CComiol's machine (Pl. IV, fig. 2) at this time (one year before it. Was patenterl) was somerwat more complicated than IIussey's and not quitesosubstantial. It was drawn byone horse hitched in shafts and walking besibethe standing gratin. 'The drive wheel was situated almost direcely herhind the horse and through a serpes of eogs gave

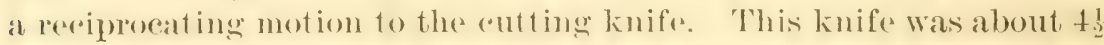
ferti long, with an elge like a sickle, and worked through wires projecting before it, which held the erain while being ent. Behind this Wats an apron or platform 5 or fi fext long, made of thin platuk, from which the grain was raked by a matn walking behind the machine. At the outer end of the platform next to the grain was a partition consisting of a coth-covered frame, to divire the cut from the uncut

${ }^{1}$ Eighth Census of the United States, 1860, volume on agriculture.

${ }^{2}$ Who Invented the Reaper? R. B. Swift, p. 6. 


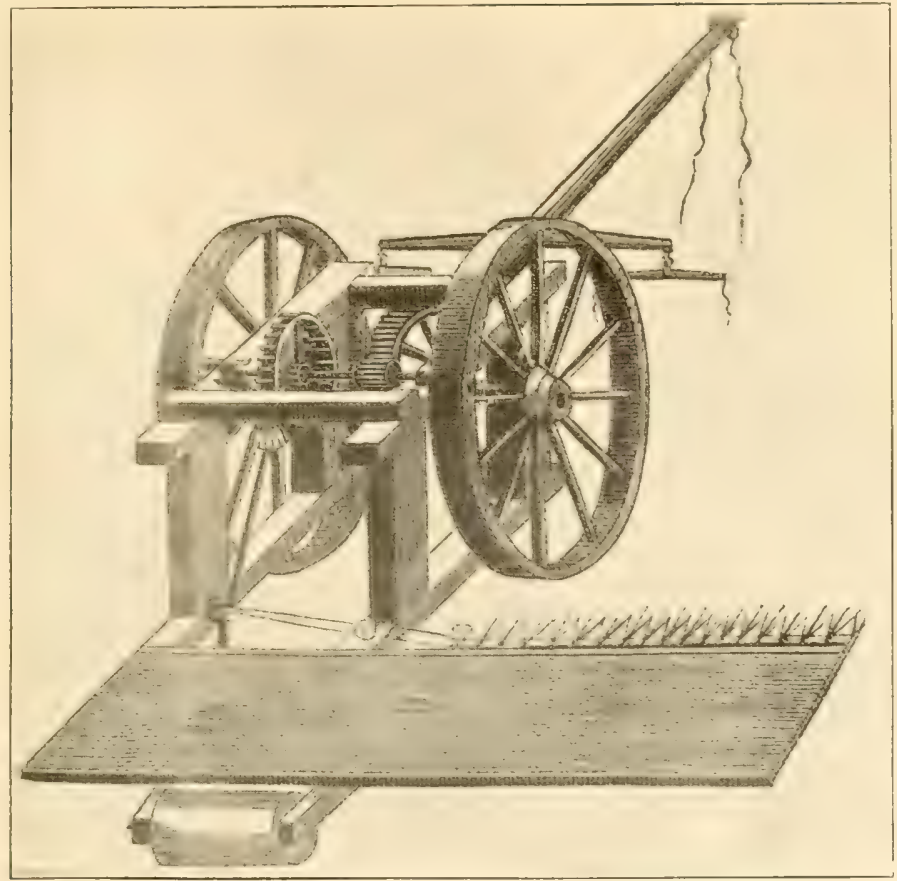

Fig. 1.-Hussey's ReAPING Machine 1833!

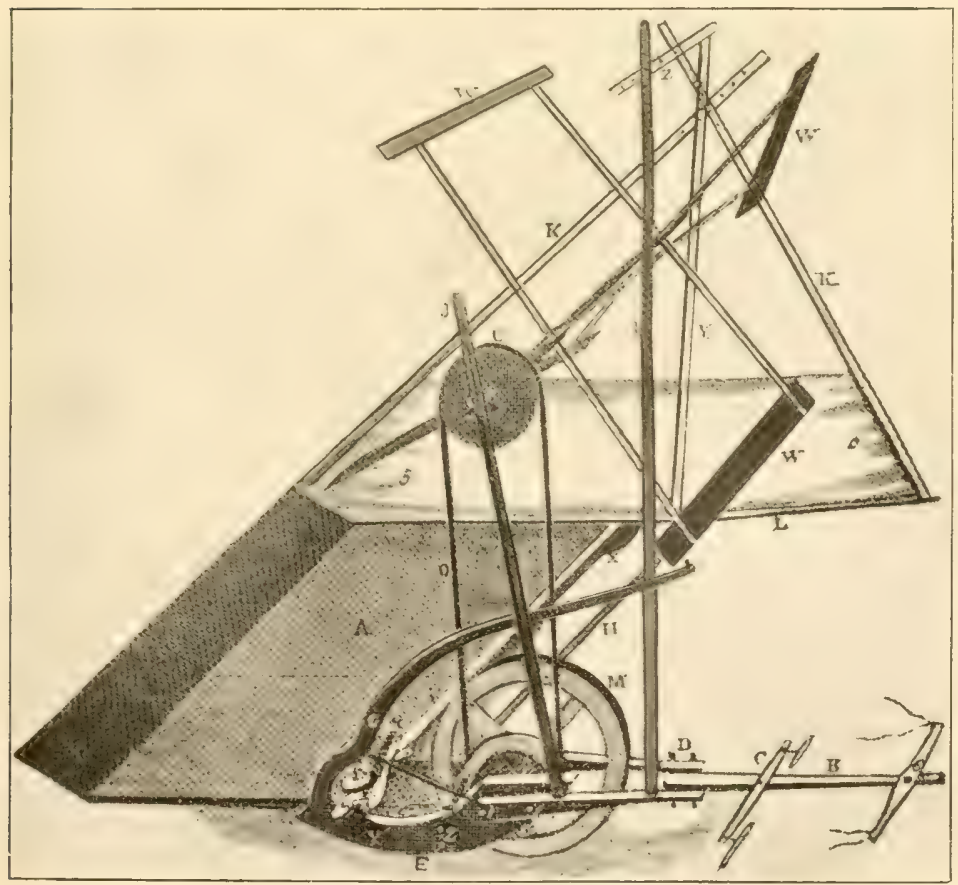

FIG. 2.-MCCORMICK'S REAPING MACHINE (1834). 

grain. There was a reel 6 or 7 feet in diameter and as long as the knife, fastened just over the eutter and made to revolve by a band connected with the main axle. This is essentially the description of the machine as given in the Mechanies' Magazine in 1833 by an Englishman who saw it working in the harvest of that year, and it may be considered an unprejudiced and at least a fair description. The patent specifications of 1834 described the machine essentially as follows: It was borne on two wheels, with a platform back of the cutter, so armanged that the sheaves were to be raked off to one side, out of the way of the next round. 'The larger whenl was on the side farthest from the grain, and by means of a crank and cogs caused to vibrate a straight-edged knife, which is described in the specifieations as "having the elge either smooth or with treth, either with stationary wires or pieces above and below and projecting before it for the puxpose of stealying the grain while cutting, or using a double crank and another blade or vibrating bar."

The machine also had a divider to separate the eut and uncut grain and a large reel to hold the orain against the knife. The patent also specifies that it is to be either drawn or pushed. 'Thus it is seen that the machine as patented corresponded very closely with the one described as in use in 18:33, so that, while the patent was not granted until the next year, Mr.Cormick as well as IIussey hat his machine at work in the harvest of 1833 . IIowever, as was stated before, McCormick's machine was undoubtedly invented prior to this time, as he hat a machine which operated in the harvest of 18:31. According to MeCormick's own statrment in his communication filed when seeking for an extension of his patent in 1848, this early machine was essentially the same as that patented in 1834. Be that as it may, it is certain that he had a machine invented in 1831 and that it was tried in that year, but that it was a success is not so evident. Hussey, on the other hand, makes no claim to having invented his machine before 1833 .

The most important part about each of these machines is the eutting apparatus, and these heing the pioneers in successful cutters they should be examined in detail.

Hussey's cutter (Pl. V, figs. 1, 2) is really a novel and surely an original feature of his machine. Although a vibrating knife had been used before, it was not like this, and nothing resembling the slotted fingers had ever bxen known. These fingers, or guards, were formed of a top and bottom piece, joined at the point and near the back, but leaving a slot through which the knife played. They were fixed securely into the bar on the front exlge of the platform at intervals of about 3 inches, and extended forward into the grain about 7 or 8 inches. The cutter, or saw, was formed of thin triangular plates of steel (being made from old saw hlades in the first machine) wheh were riveted side by side in a flat bar. They were $t_{2}^{\frac{1}{2}}$ inches long and 
: inches wide at the base, but terminating in almost a point. 'They were sharpened on both edges and beveled from both sides, unlike the present mower sections, which are beveled from above only. T'he action, then, was not on the shearing principle, as in Bell's machine,

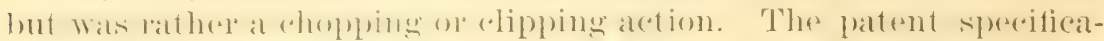

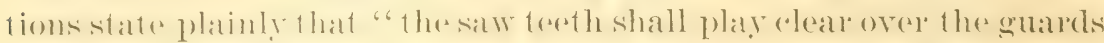
both above and below," so that the invention could not have been ropied fom liclls shearing plan, as has sometimes been chamed. The doubly beveled sections and closed guard were soon found to be faulty, as the cutters were especially liable to clog. Another feature had considerable to do with the clogging and also increased the clraft greatly, i. e. the acute angle which the blade formed with the guard. In order to remedy this diffieulty some changes were soon marle. The blade was shortened and marle more obtuse. About an inch of the extere of ateh hlarle neat its hase was heft flat helow and bereled only from above, in order to shear the trash and grass which gatherest in the hatek part of the shot, and hastly, the guater, insteat of having a closed slot, was open at the back and upper part, this last

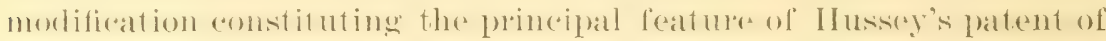
August 7, 1847. As time went on and many inventors applied themselves to the improvement of this form of cutter, more and more of the edge of the blade was left in contact with the guard below, and the blate became more and more obtuse, approaching more nearly the shape of the mower sections of the present day. Thus it is seen that while Hussey's invention contained foatures vital to the reaper;

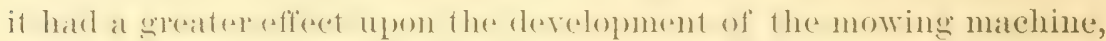
and was more strictly a type of mower than of reaper.

MeCormick's cutter (Pl. V, figs. 3,4) as first used consisted of a

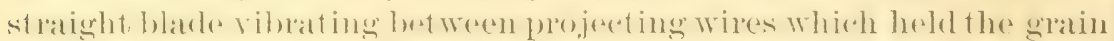
while being cut. 'This blade, as the patent specifications say, was "aith, smooth of with forth," and very probably the first matchines

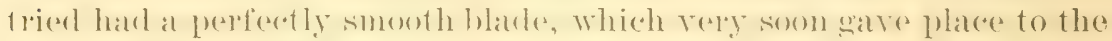

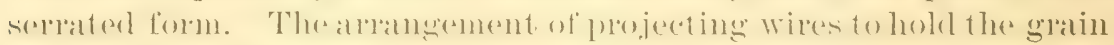
while entting was also used at first, but later a sort of finger was

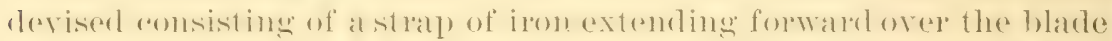

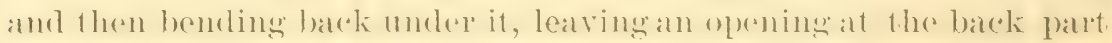

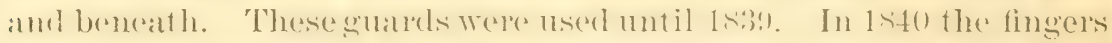

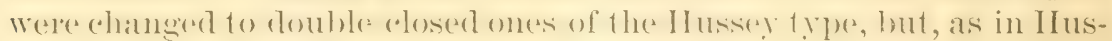
sey's machine, this rosed finger hatel a temdeney to catuse cloggringr, and was changed for a later style as patented January 31,1845 . In list! a rhange was mate in the sermations on the hade, making alternated groups of teeth to point toward each other, so as to incline

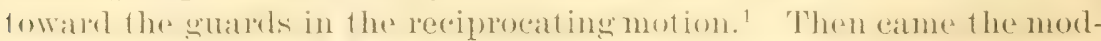
ifiration of the entards, as ahove mentioned, ohatnging them to spearshaper projerelions, flattened horizontally. both these changes were 




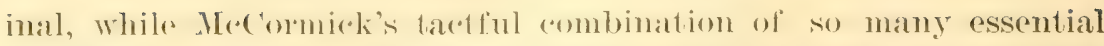
features, whether original or not, did womkers toward furthering the development of harvesting machinery.

In the early trials of these machines the honors sometimes were taken by one and sometimes by the other; but it was noticed that, while IInssey's was simplere and more durable, it pulled heavier and gossessed the lisalvantage of refuluing the wheat to be bound before a secomt romel of the machine, since the sheaves were raked directly backward off the platform. It was, however, more to be depended upon than McCormick's, excepting in wet or green grain, where MeCormich's seemed to have the advantage.

Few of either machine were sold for several years. According to McCormick's own statement, in an account of his progress, written for Philip Pusey, esq., of England, "No machines were sold until 1sto, and I may say that they were not of much practical value until the improvements of my second patent in 1845. Up to this period nothing but loss of time and money resulted from my aflorts." 1 The improvements referred to seem to have increased greatly the efficiency of the machine, for in 1851 more than one thousand were sold.

Iaving considered the two fonndation mathines, we maty now notice the varions improvements and modifications which have appeared in developing the marhines of the present day. The patents and inventions are so numerous, however, that it will be possible to give only the most important, or those containing some essential features of the later machines; and as the mower and reaper wre at first often combined in the same matehine, sonne of the earlior patents referring to mowers must also be mentioned. The mower was at first simply the reaper dismantled of its platiorm and other parts not nefoded for grass cutting, although sefarate machines for this pupose were early constructed. As the mower required a higher speed of the knives than the reaper, no suressful 1,y of of this mathine was constructed until a device for accomplishing this end was invented.

Enoch Ambler, of New York, ohlainerl a patent I)ecmber :23, 18:34, about which little can be learned. It is understood, however, that he had the first wought-iron finger hat with sterel gualls and shoes. There is some difference of opinion as to the worth of this invention, but the finger bar seems to have been somewhat in advance of the times, resembling the later forms of the McCormick and Hussey machines.

Abraham Randall (or Rundell), of New York, April 22, 1835, patented a curious cutting device, consisting of two sickles or cutters

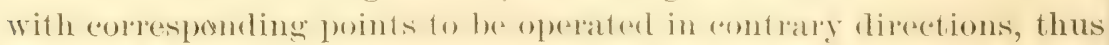
making a dolible sheal cut with each pair uf points, the whole acting as a series of doubleateting shears. If was one of the most important, of a number of inventions on this principle which were mate in this

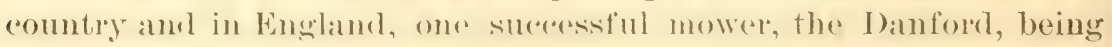


upon this principle. 'This Randall machine also contained a raking and discharging device, which was among the first atitempts at an antomatic rake. Up to this time the raking hat all been done by haud f hut now, after the essential parts of the realper were workerl out, inventors began to endeavor to perfert, the machine and to solve the problem of a successful automatic device to remove the grain from the platform.

The early devices for antomatically removing the grain from the platform were valied and often crucle. It will be remembered that, Bell user an endless (anvas to lay the grain in a swath at the side, while Crosskill's English morlification of MoCormick's marehine several years later used a number of Archimedian screws to accomplish the same purpose. 'These and numprous other derices were tried, such as reciproeating hars with pous to work the grain to one side and rake teeth penetrating a stationary platform below, as in Reorl's machine (see below). Finally, among the numerous attempts along this line came that which oporater with lakes above astatiomary platform, the type from which the self-rake was at last developed. Among the first of this class were the single-ralie tylex, which raked directly batekward with a horizontal motion. ()thers hatrl a rake fastenerl to the reel, while some had single lakesswexplug a fuadrant platform. Finally came the revolving fans, either on a vertical or an inclined axis, one of which raked the platform. Later the vanes or fans were all mate alike, eateh being capable of sweeping the plat form at the will of the operator.

One of the first patented inventions which sought to deliver the gavels automatically was that of riohnebly, patented in 1s:3:). It had a horizontal endless apron, trancling intermittenty and thus delivering the grain in gavels by the side of the machine. In 1 siss cyrenus Wheeler invented a marhine with a revolving endless apron to deposit the grain in a box with a sliding bottom which could be opened, thus dropping the grain in gavels. Jonathan Recel patented a matehine March 12, 1stz, that had a rake beneath the platform with teeth projecting through the slots to remove the gratin in gavels. He also introduced a form of eutere which possessed the peculiarity of serrated guards in combination with strated cutters, but this never seemed practical. Clinton Foster, this same year, April 1s, patented a form of rake which swept across the plat form as controlled hy the operator, and November 20, 18t1;, Andrew Cook patented a rake which was attached to the reel, forming a revolving resel rake, the first of its class. This latter machine was afterwarls manufarotured hy Goble and Stewart aud had a revoiving canvas, back of the platform, upon which the grain was swept by this revolving rake and thus transferred to the ground to one side.

${ }^{1}$ McCormick's original patent provided for a similar device, i. e., two knives working in contrary directions, as well as for the single reciprocating knife afterward exclusively adopted (see Progress of Invention in the Nineteenth Century, by E. W. Byrn, p. 19s; American Agricultural Implements, by R. L. Ardrey, p. 4J). 


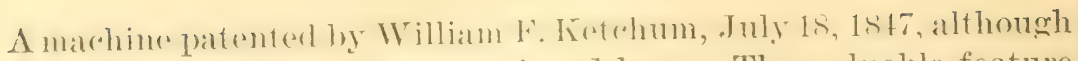
built as a mower, should be mentioned here. The valuable feature was in the cutter bar which was made to sweep the ground only the

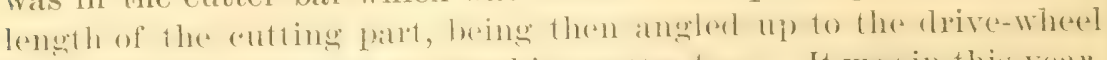

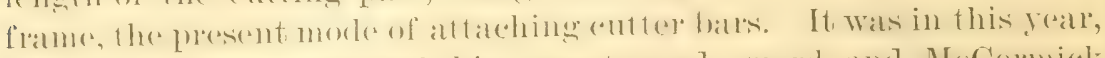

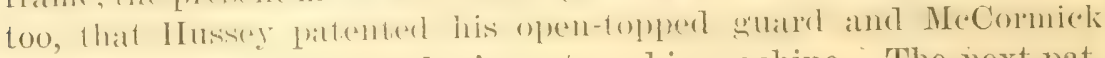
roceived a patent for a raker's seat on his machine. The next patent for an alitomatic delivery was that of F. S. Pease, November 14,

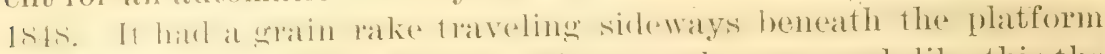
with silde slots for the fingers. Mamn mate one much like this the next year.

On November 21; 1848, Goble \&. Stewart patented a rotary rake

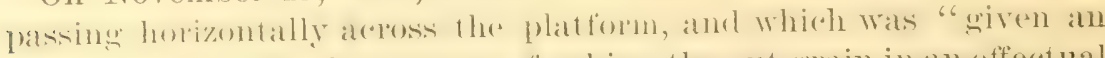
une(pual motion for the purpose of raking the ent gratin in au effectua! matnmer." I)aniel (ushing abest. lhis tims louk ont. a patent for an apparatus with revolving rakes. The next year, January 16, Oliver

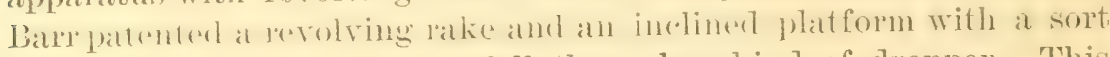
of trap door for the grain to fall through, a kind of dropper. This

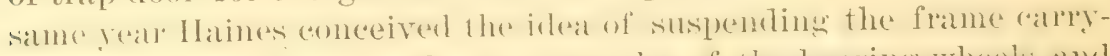

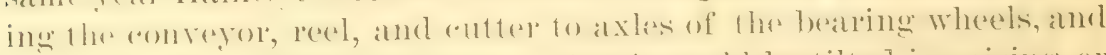
hingent the frame to the tongur so that it rentel be tilted in rasing or lowering the cutters, an important improvement.

A. J. Purviance, of Ohio, May 22, 1849, obtained a patent for constructing the platform separate from the other framework so as to convert the machine into a mower or reaper as required. 'This was

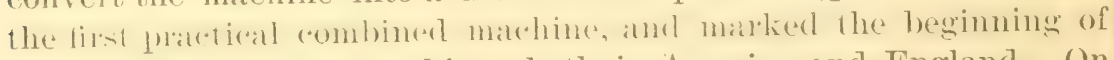
the long list of such machines both in America and England. On June 12 of the same year an important patent was taken out by Nelson Platt, which was afterwards assigned to Seymoux \& Morgan,

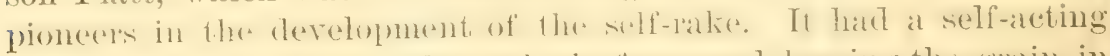

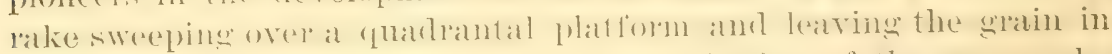
gavels at the side of the matrine. It wath he first of the sweeperake system which afterwards became so popular. On Tuno 19 of this

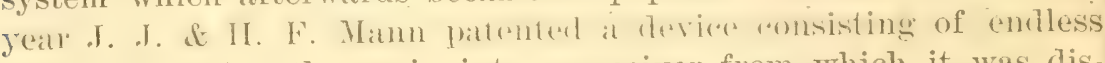
bands delivering the grain into a receiver from which it was discharged in gavels by an attendant.

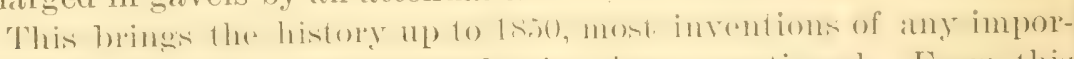

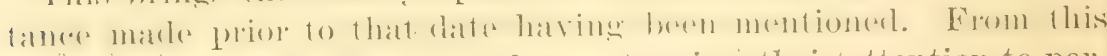
lime on inventors by the score began turning their attention to perfecting the means of delivering the grain, and patents became so numerous that it will be possible in this treat is. to mention only those most essential to the development. About this time, as the machines

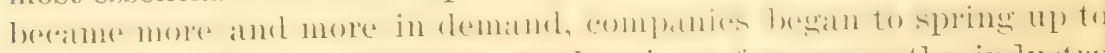

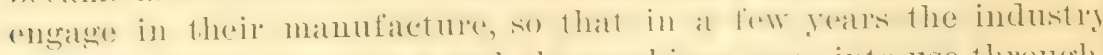

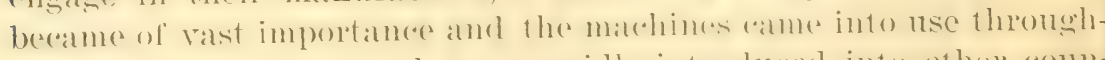
vut the United stattes and were rapidly introduced into other coun- 


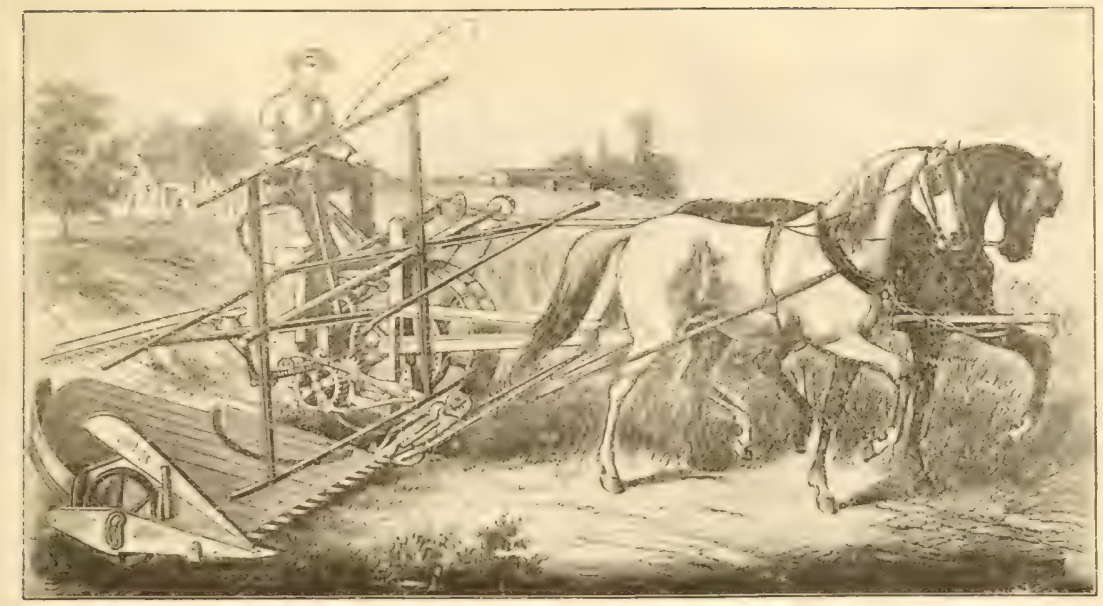

FIG. 1.-AN EARLY FORM OF SELF-RAKE-THE NEW YORKER.

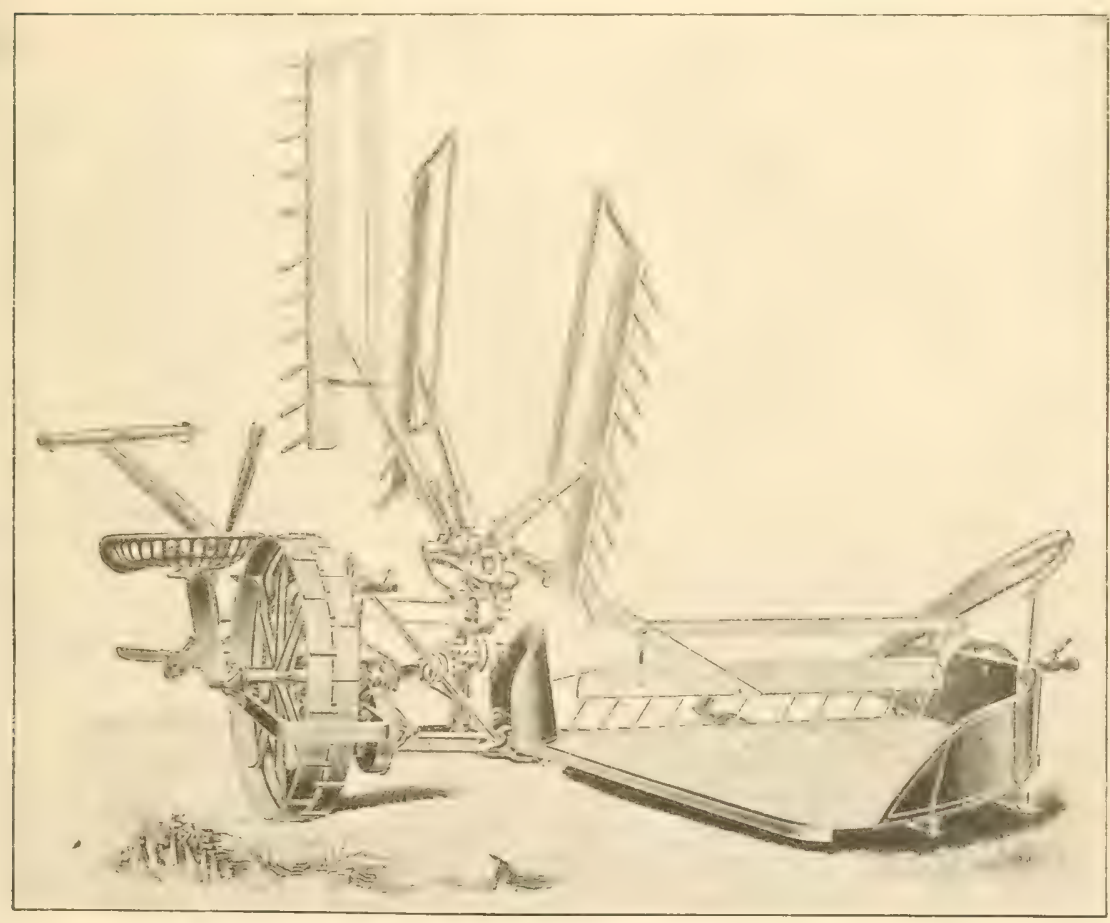

FIG. 2.-A MODERN SELF-RAKE. 

tries. Within ten years the mowner beeame practidally what it is 10-6lay and another decade saw the fomelation of the molern hinder practically laid.

The year 1850 was not remarkable for important inventioms. E. Danford patented an improvement on a double sickle and produced a mower which was very effective. It was so perfect as to be able to cut through a cork of hity, hut the diffoulty of kexping the knives free of the gum on their adjacent surfaces was so great that the

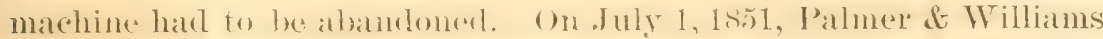
obtained a patent for a sweep-rake and quadrant platform. This platform was similar to that of the improved self-rake, but the rake was a single attachment made 10 swe(2) the platform horizontally at regular intervals. Assigned to Seymour \& Morgan, it entered into their system of self-rakes. The same month a patent was taken out

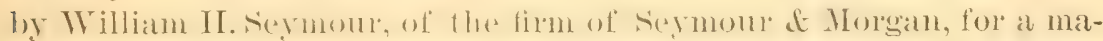
dhine differing little in wsential principles from the alowe. The rake swept the platform every 14 feet, or at the will of the operator. This machine became very popular in the East and was known as the

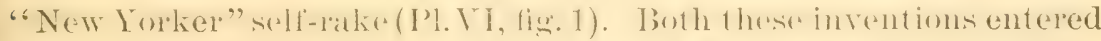

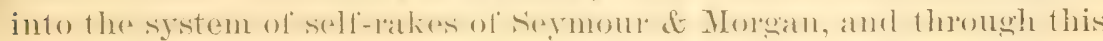
firm much was done toward perfecting this machine.

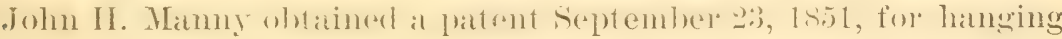
the cutter bar to the side of a triangular frame so that neither end could sag; also for a forker's stand back of the outer end of the platform. It had sickle-edged knives and the eutter could be raised or lowered at will. It could be used as a mower by detaching the platform, but was objected to as being too cumbersome. It was one of the earliest successful ambinesl machines and latil the foundation of the reaper business of Rockford, Ill. R. T. Osgood obtained a patent

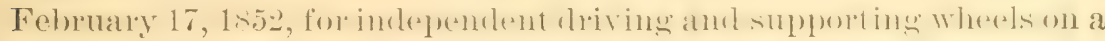

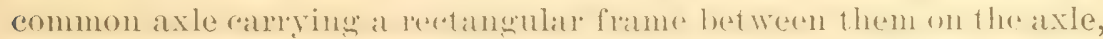
also providing eatro rlrive wherel with latchet, wherel and pawl as used

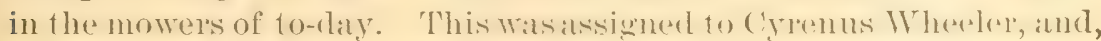
together" with other's, herame one of the base patents of the "Cayuga Chief," a very popular machine of that day.

The next important invention is that of Jearum Atkins, patented December 31, 1852. It was known as the Atkins Automaton from the action of the rake. This rake was rigged on a vertical post and had

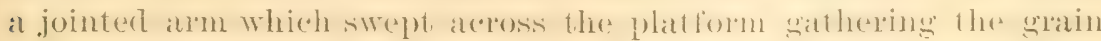

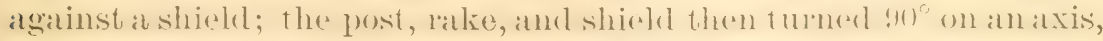

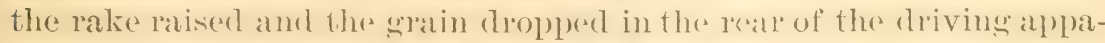
ratus. It worked well for a time and had a large sale, lout was finally abandoned.

In 1852 a man by the name of Ifoffhein profluced a rake that could operate as a reel-the early form of the revolving vane used on the reaper of to-day. The device consisted of a vertical shaft carrying 
four reel arms so geaned as to swere the platform at recular intervals. The rakes were in pairs upon cosss shafts and the latter were arranged to rock, so that when moving over the platform they would come colose to it, but in the rest of the perolution they were high above the gearing.

September 20, 1s5:3, Philo sylla and Augustus Arlams obtained a patent for a machine which carried these mon upon the platform to bind the eut grain as it was forked or shoved around to them by a fourth man. An important feature of this machine was a finger bar hinged to the main frame so as to allow the bar to "vibrate perpendicularly and accommodate itself to uneven ground."

A. J. Cook, who had received a patent on a revolving reel rake in

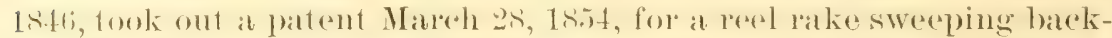
ward, which was assigned to Cyrenus Wheeler. Abner Whitley, Septrmber 1s, 1sit, obtained a patent for suspending a rake to one of the reel blades, a very important patent.

In 1555, .J. E. Newcomb obtained a patent for a (lroplere, which was assigned to J. F. Sieberling, of Ohio, the acknowlerlged head of the dropper system. The hropper as now used eonsists of an attachment behind the eutter bar, which holets the grain until enough has been aceumulater for a sheaf, when it is lowered and the grain allowed to slicle off. 'The first invention along this line was by Ogle (1822), who had some such arrangement on his machine (1) 15). Other devices have been used, such as one by Wheeler, in 1s:3i, which delivered the grain by a canvas into a box, from which it was dropped (p. 29). The most improved form, however, consists of a number of slats fastened to the rear of the cutier har, and which may be raised and lowered at the will of the operator. It is used to some extent at the present day, especially for particular purposes, as for bunching elover when cutting for seed.

In 1856 Owen Dorsey patented a self-rake which was an improvement on the Moffhein type, and was an important patent, in the devolopment of this form of machine. It is operated much like the IIoffhein machine, having "rakes which rise and fall as they rotate, and as they approach the front part of the plat form deseend to the level of the latter and sweep over it, raking the ent grain therefrom, and then rise at the discharge end of the platform out of the way." At first the operator could not. ride, but this diffroulty was orereome by the patents of T. Whitenack, February 5, 1861, and of others. 'I'his is the first patented invention of revolving reels on a vertical axis, as the invention of Holfhein was not patented. At this period there were a serat number of devices using simply a single rake for swep)ing the platform, but with the last-mamed invention the first types of the present self-rake made their appearance.

D. M. Osborne and W. A. Kirby, Fobruary 10, 1s57, secoured a patent eovering a reel supported on a single post, a feature afterward incor porated in the Kirby, a popular machine of that day. 
Both rigid-bar and flexible-bar machines now eame into use, and especially among mower's were these distinctions important. There were the two divisions, the single-wheel rigid-har type and the twowhecled flexible mathine. Reapers were also affected by thanges in this lint and were made like the mowers in both ways. A patent granted to Lewis Miller May 4, 1,57, combined the reel with hinger platform, so as to preserve their relations on even ground, a rery

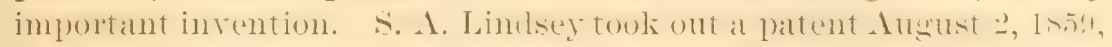
for a reed rake arranged to aterommodate itself to a hingerel plation, also covering the important combination of a quarrant platform, hinged finger beam, and frame supported by two wheels. The next year, September 18, McClintock Young obtained a patent for a "combination of a revolving reel shaft carrying diverging reel gatherers supported at one end only, the fixed double-walled cam and the rake

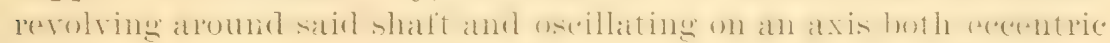
and transverse to said shaft, with counterpoise to equalize the movement of said rake." The shaft of this was not rertical, but resembled that of the ordinary horizontal reel, and shows the manner of developing an important feature from the forms that preceded it. This invention is of special importance, as it was the foundation pitent of the Mrecormick self-lalie. The Whiteley patents, embodied in the Champion machine, were taken out at this date. In 1862 James S. Marsh took out a patent for a revolving rake and reel, the arms of which were hinged to the revolving wheel independent of each other. Finally, may be mentioned the patent of samuel Johnson, February 7,1865 , for his celebrated reel rake, in which all the revolving arms carried rakes and were each hinged independently and all controlled by the operator. This was the Itoffhein type practically completed, and needed but detailed improvements to make the self-rake of to-day. With this patent the self-rake was virtually (omplete, and thereafter the many inventions referring to it were only in details. (See Pl. VI, fig. 2.) It had not long to remain king, however, for by 1870 the binder was coming into use, and the fate of the self-rake, except for particular places or purposes, wats practically sealed.

\section{HARVESTERS.}

The term "harrester" may, in its broalest sense, be applied to the modern self-binder as well as to the heater of the Western platus and of Australia. Long before the self-rake hat reatcherl perfection, invention hat been going on in both these directions and rapious forms of machines hat betu devised. Even hefore a llatetical cutting apparatus had been produced afforts were being put forth toward making at device for heating and threshing grain, and also to discover some mode of forming the eut grain into sheaves.

8910-No. 103-02-3 
BINDERS.

Taking up first the efforts made to construct a machine having an atutomatic binding apparatus, it is desirable that such machines be divided into two general classes: (1) Those in which the hinding device is attached to a marhine of the self-rake pattern, called the "lowdown" class, and $(2)$ those in which the grain is elevated to the binder, as in the present form of the machine.

Eamly devions for hinding were rery eride and differed greatly from the present form. Materials used for the band in these early forms were of thres kinds-straw, wire, and twine-rarious attempts being made to use each of these materials. Many of the early devices, although antomatic in the binding, refuired an attendant 10 furnish the power, while others required an attendant also in helping to bind.

The first attempt on record to bind grain by machinery was by John E. ITeath, of Ohio, whose patent was granted July 22, 1850, and called for a twine or cord bincler.7 In claims in patent specifications were: "First, gathering the grain and compressing it into a sheaf, substantialiy as herein set forth, hy means of the rake and staudard; second, carrying the cord around the sheaf and holding the latter until the band is tied by means of the curred lever 7 and toothed arm y, substantially as herein set forth; third, the employment of split thimble aut sliding hook to aid in tying the hand." Two more claims are mentioned, but they need not be noticed here. Little is known of this binder except from the patent. It was on the "low-lown" prin(-iple, as were all the early machines and the lake mentioned in the first claim worked beneath the platform. ${ }^{1}$

TTwo patents, one in 1 s.51 by Watson, Renwick, and Watson, and one in 1855 hy P. II. Watson and Renwick, foreshatowed the modern binder in great measure, but were too complieaterl to be practical or to allow of description here. The inventors were men well alequainted with patent-oftere methods and made the patent corer so many features that it was a stumbling block to later inventors. Their great complexity remblem the machines valueless, although showing eon-

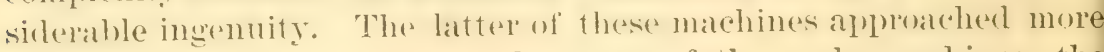
nearly to the modern binder than any of the early machines, the grain being carried by a series of revolving bands to a sort of crib, where it was bound automatically with cord. It, however, never got beyond the experimental form.

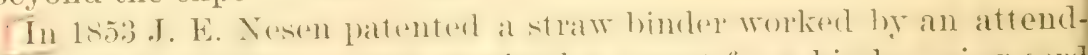
ant, and (reo). Yost, in lsiti, peresived a pattent for a binder using cord rut into longths for hinding. which was also workerl by an attendaut.

The next device which need be noticed was invented by C. A.

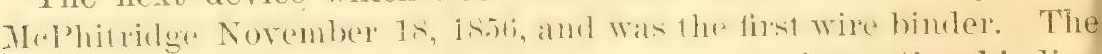
wire was coiled upon a reel and delivered to a reciprocating binding 


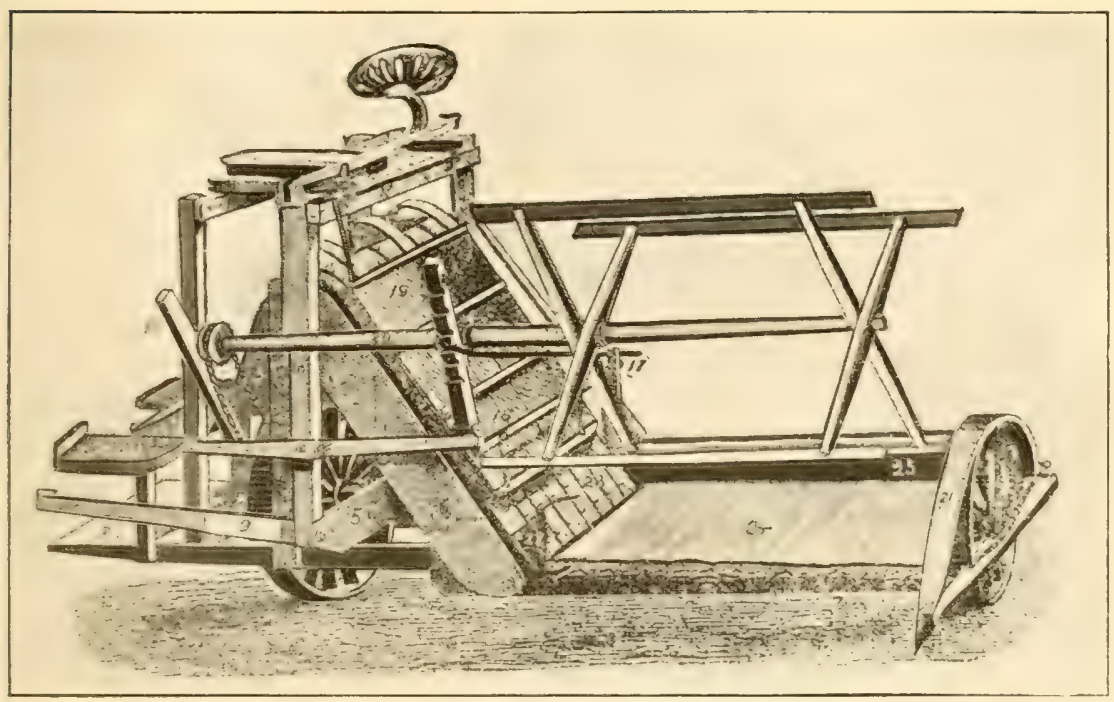

FIG. 1.-THE MARSh HARVESter (1866).

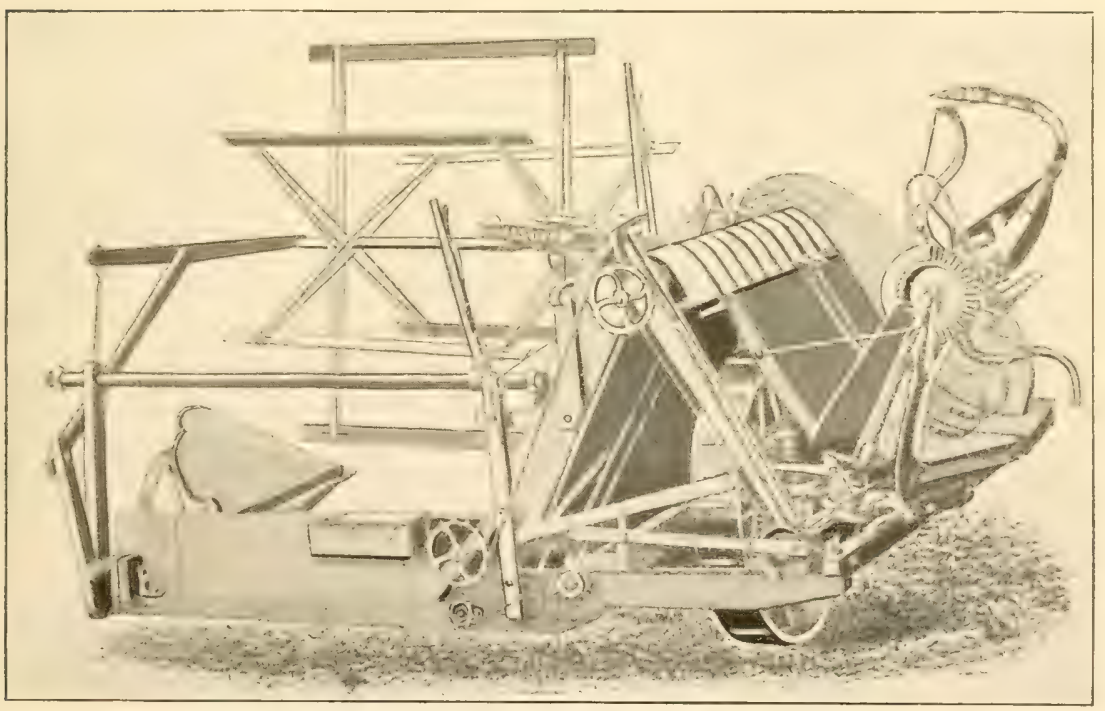

FIG. 2.-A SUCCESSFUL WIRE BINDER-LOCKE'S (1873). 

patent spureifications to have had "a hinding knot romposed of three loops passed through each other," ete. 'The cord or twine was taken from a reel. Again omitting several unimportant devices we come to that of II. M. and W. W. Burson, patented June 26, 1860, which was a twine binder to be used upon any reaper, and which tied by means of hooks working together. It was not automatic. 'The next year the Bursoms brought out a wile binder, which wasthe foundation of a machine that made a greater sensation and came nearer being a success than any of the "low-hown" type, although the binder was worked by an attendant. The feeling against wire for binding was so strong that in 1865 he substituted a knotter for the wire-binding derice, and had a twine binder at work in that year(4) But the price of twine, the necessity for a man to work the apparatus, and the influence of the Mans haprester, then hecoming so popular, doomed his machine to failure After this mothing "ame" of the "low-rlown" type of machine, and although many patents wele taken ont for hinding deriees, none became popular excepting those which were applied to the Marsh pattern.

The next important invention was that of Jacob Behel, patented February 16, 186t. It was the knotting bill which is used with little modification on almost all binders of the present day. Connected with the bill was a turning cord holder, consisting of a small notched wheel which held the cord. The bill seized the portions of the cord which were to form the knot, and looping it, moved past a knife which cut it off in the proper place, leaving the end of the cord from the ball firmly held by the turning wheel. Mr. Behel took out other patents, and by 186 o had a knotter which worked well.

May 31,1870 , a patent was taken out by George $H$. Spaulding for an improved grain binder of the Marsh harrester type. This machine contained the important feature of an automatic binding mechanism which made bundles of miform size. 'The value of this invention was quickly recognized by manufacturers and incorporated in their machines.

The next name that should be noticed is that of Sylvanus D. Locke, who first took out a patent for an automatic binder in 1871. He took out rarious patents and macle a fairly successful wire binder, which he finally attached to a harvester of the Marsh type through the aid of Walter A. Wood. 'This machine was firt put out in 1873, and became a popular machine of that time (Pl. VII, fig. 2).

While Locke was perfecting his machine James F. and John $H$. Gordon, in comnection with Mr. Deering, of the Marsh Harvester Company, were working on a machine, also of the wire-binding type. John H. Gordon produced his first "packer" binder in 1873, and his brother soon after brought out what was known as his "crane" wire binder, both machines becoming popular. 'These machines were put out by Gammon, Deering \& Stewart and by D. M. Osborn \& Co., 
while C. H. and L. J. McCormick soon began the manufacture of the Withington type of wire binder, one of the most successful wire binders ever put out. It differed from the Gordon and Locke machines in its chain movement, in having two spools of wire from which the bands were formed, and in other derices. All these were attached to the Marsh type of machines, and were fairly good machines. But about this time, when wire binders were becoming widlely used, and when it sermed that these companies had the matket in their power, the cord binder forged to the front and the wire binders were doomed to extinction.]

Of the cord hinders which hat heen devised up to 1s75, when the wire binders were coming into wide use, several were raluable, but the one by Behel contained the principles that were to last. In 1875, however, John P. Appleby, who, as early as 185S, had invented a successful twine knoter, but who hat since that time heen deroting his time to wire binders, again turned his attention to cord machines. Ife connected himself with Parker of stone, of baloit, Wis., and with their aid built an automatic binder that promised well. It was the foundation of the binding apparatus which is used on almost every binder to-day. It combined the good points of the preceding inventions in a spat dewere, with some principlesoriginal with the inventor. It underwent improvements during 1876 and 1877, and through the aid of William Deering was still further perfected during the two following years. By 1880 it was practically perfected, and 3,000 were put upon the matket. The I)erering, McCormick, Champion, and Oshorn companies at once precured rights and hesan the mannfacture of this type of bincler in combination with the Marsh style of frame, adding vallous imporovements in letails as they saw fit. This stye of machine immerliately leaperl into popular favor. All others wereson distanced in the race for superiority, and the binders of the present are simply this type of machine more nearly perfected. From that day the modifications have been in detail and not in principle. It is true that among the twenty-oblel manufacturess of machines there are found types differing comsiclerably from this, hut they ane not among the most popular machines.

\section{HEADERS,}

The first attempts at a reaping machine were probably in the form of a header. In regard to the first historical aroount we know this to bes true, for Pliny deseribesone at work (1). 12) in the fieldsof (ranl, which was of this type. It is probable, too, that some forms of the harvester were in use by the ancients, of which we have no record, since historians gare their attention to other than agricultural subjects. The earliest English machines were also after the form of the old Gallic stripper, so that this mode of harresting is not new. In America various attempts have been made to censtruct heading machines, the 
trials reaching back to the earliest inventions in reaping machinery, while from the very first, attempts were made to build a threshing apparatus in connection.

As early as 1825, Samuel Lane, of Maine, obtained a patent for a machine which was a combined havester and thresher, a very ingenious but complex machine. It never went bevond a patent, however. Various other machines were constructed, seeking to combine the reaper and thresher, a few of which may be mentioned.

I mathim for harresting, threshing, (teanimg, and hagging grain was patented June 28, 1836, by H. Moore and J. Hascall, which contained many ingenious deviexs and might have proved a suceess, with some improvements, had the great fields of the Western plains and Califomia been developed at that time. In the climate of the more eastern States it was impractical and never became a success.

In 1845 an Englishman by the name of Ridley, then residing in

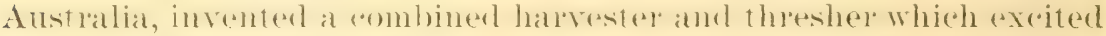
much comment at the time. It was made to be pushed before the horses and the heals were torn off by a comb-like device much after the style of the ancient machine of Gaul. The elimate of that country being favorable for the use of such machines it was used to a considerable extent. Perfected types of the combined harvester and thresher are used to a considerable extent in Australia to-day.

On October 2, 18t5, George Esterly, of IV isconsin, patented a harvester which was a noted machine in that day. It had a reel which severed the heads by striking the straw against a knife on the front of the machine. 'T'he heads were collected in a box on the back part of the machine just in front of the horses, which were hitched in the rear.

The next and most important invent ion was that of' Jonathan IIaines,

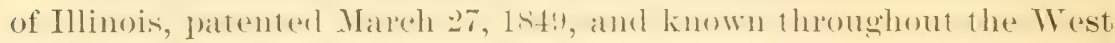
as "Haines's Illinois Harvester." As improved, it was a thoroughly practical header and large numbers of them have been sold. It had a device for raising and lowering the cutters, and cut a very wide swath. It is this style of machine that is now used in great numbers on the plains of the West. This machine (-Pl. VHI, fig. 1) is fitted with a very lomg cutter-bar and reel, and by means of a long, eanvas elevator carries the heads to one side, where they are depositer in a wagon with a bed fitted for the purpose. It is pushed hy attaching four horses abreast to the tongue in the rear, and guided by a wheelsteering device. Six men and ten horses can by the aid of this machine cut and stack from 15 to 30 acres per day.

In some parts of the West, especially in California, where there is no fear of rain during harvest, a combined harvester and thresher is used, which hearls, threshes, sepallates, and saloks the grain (I'l. VIII, fig. 2). It is propelled either by a traction engine or by horses. If horses are used, from 30 to 36 are required, and if steam is used more 


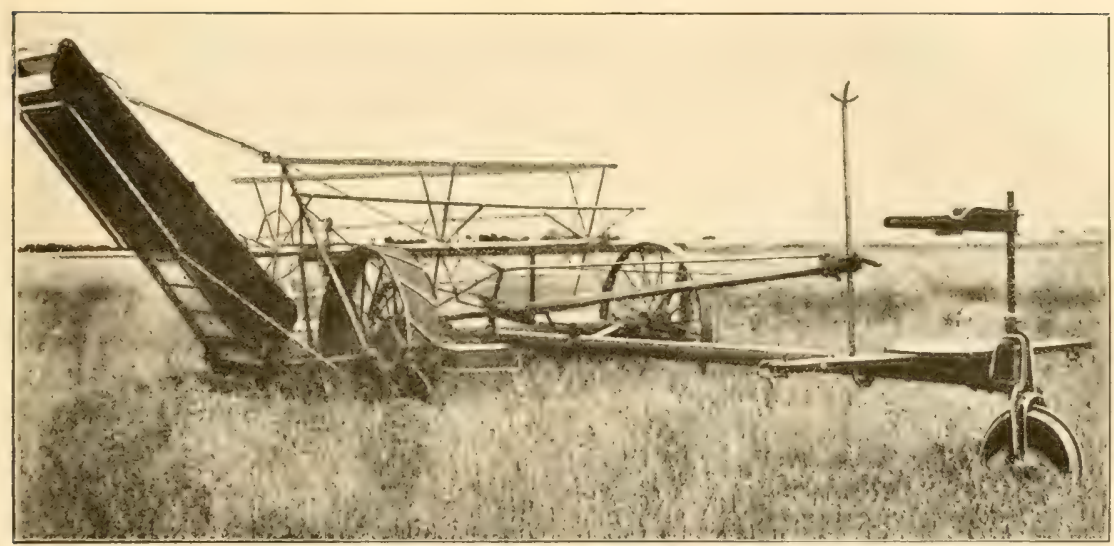

FIG. 1.-A MODERN HEADER.

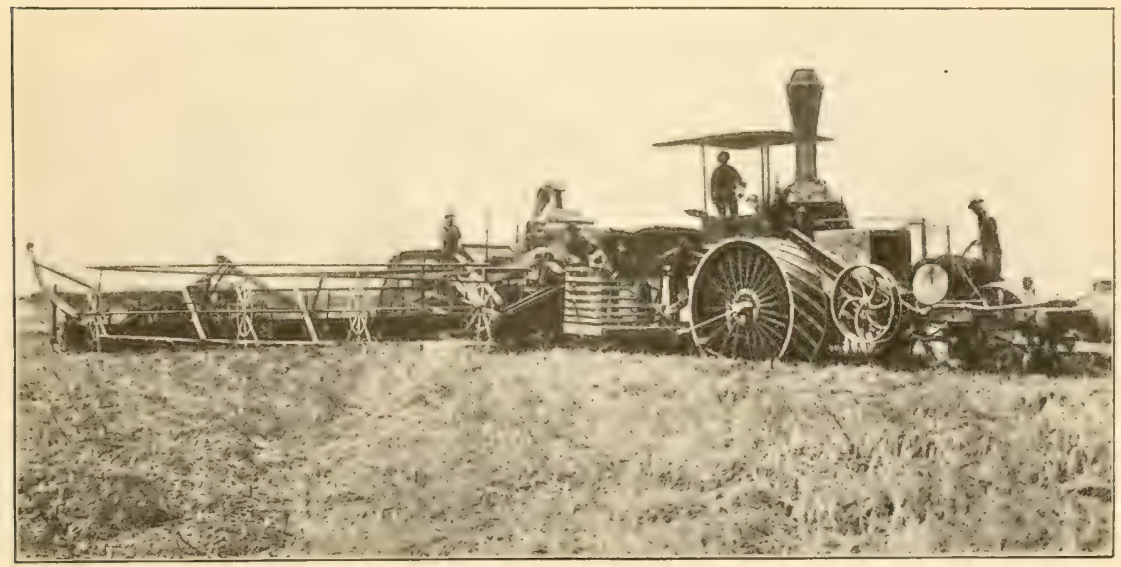

FIg. 2. - THE COMBINEd HARVESTER AND THRESHER. 

men are needed than if horses furmish the power. The machine has a capacity of from 60 to 125 acres per day or from 1,700 to 3,000 bushels. These machines have done a great deal towat dereloping the immense wheat ontput of the Western comtry ame shomld hold no small place among the harresting appliances of the present day.

American harresting machines are the most perfect in the world, and to-day they are being introduced into almost erery country on the globe. In $18 \pm 0,3$ reapers were made in America; in 18 15,500 were made and 50 people were employed: in $1850,3,0)$, were put out:

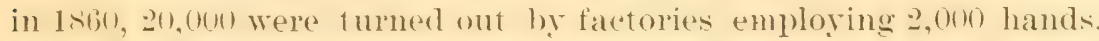
During the next ten years the increase was not so rapid, but in 1570 30,000 were built by $5,(110)$ employees; in lsin, bo, 000 machines were

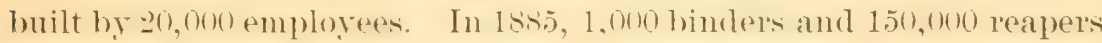
and mowers were constructed by 30,000 employees. In 1890 two manufacturing establishments in Chicago mate more than :mo,ono machines, half of which were binders and the other inalf reapers and mowers, and in Isteg more that one single firm exceeded that number.

\section{MOWERS.}

In the early development of the mower, it was so intimately connected with the reaper that a little space should here be devoted to a short review of its history. Hussey's first machine was really a mower, and it was nom this principle that the mower was afterwats built. Many of the early machines contained combinations of the mower and reapere, and were used with a little arljustment to eut either grain $\mathrm{or}^{\circ}$ grass.

The idea of a separate machine for cutting grass was conceived in Americat, the first attempt to construct such a machine besing hy Peter Gaillamel, of Penmsylyania, whose patent was dated December t, 1size. The mathine was mot sucoessful, homever, and it is rematrahle only as heing the first. The next was hy Jeremiah Bater, Febuary 13, 1820 (see page 23 ), and was on the revolving-cutter plan. It gained some notoriety at the time, and worked with a slight degree of success. Another important inrention was that of Wm. Manning, patented May 3, 1831 (see page 23). It was really a reaping machine, but con1ained the principhe of thereiprocating knifir which afterwarlshecame so famous as the basis for all mower cutters.

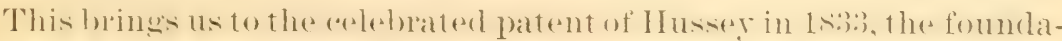
tion of the morlern mowers. II knife and slotted guards is used with some improvements upon all mowers of the present lay. Ifussey loneleht out the principle: others helped to perfect it. The history of the mower from 1833 to the present day has been simply a perfecting of this type of cutter bar, and the working ont of certain necessary details.

In this development there were two elasses of machines: (1) Those having a rigid bar and single drive wheel, and later, (2) those having 
the double drive wheel and flexible bar. In the first type there was sometimes a smallor whel to support the cutter bar, and sometimes none; while in the latter the cutter bar was jointed to the machine, and had, if any, only a small roller at the end.

A name that stands out prominently in the development of mowers is that of IVilliam F. Ketchum, who has sometimes heen spoken of as the father of the mower trade, since he was the first to put mowers

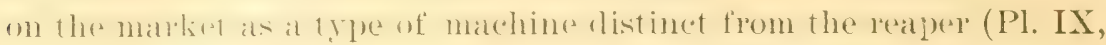
fig. 1). IIt took out several patents, but the one granted July 10, 1847, was of especial importance. The main features of this patent were the unobstructed space left between the driving' wheel and the finger bar with its support, and the remarkable simplicity of the machine. The cutter was an endless chain of knives, which never became successful, but which caused some excitement at the time.

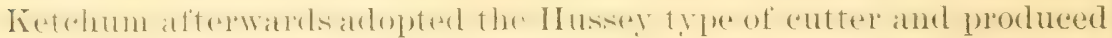
a very successful mower of the rigicl-bar type. It was this machine that led the way in mower development and became the first really practical machine.

In 1850 Ebenezer Damford, of Illinois, patented a machine with a double knife cutter, previously described (p.31). 'This was a strong machine and one of the most successful up to this time. By 1855 this type of the fixel-hat machine hatl been perfected, hut it lay with the flexible-bar machines, which were now coming into use, to sweep from the market the former type.

The first invention showing the feature of a flexible bar was that of IIazatrl Knowles, the mathinist of the Patent () ffice at Washington. It showerl many valuable features of a reaping machine also, but no patent was taken out. The patent granted to Cyrenus Wheeler, December 5, 185t, marks the division between the two types of machines. Wheeler was a pratotical man, and, like Mcorornick in the development of the reaper, succeeder in combining so many important features in his machines as to give him a place as one of the foremost pioneers in the development of the mower. The machine of $180 \pm$ was not a success as constructed, but the features of two drive wheels and a cutter bar joined to the main wheels were lasting.

A careful study of the reports of some of the mower trials which ware held about this time would be of use in showing what machines were then in use and to what degree they were practical. At a trial of mowers and reapers at Springfield, Ohio, July, 1852, three comhined mathinesand thees mowers were entered. The combined types were hy Macomick, Purviance, and simith, and the mowers by IIussey, ('astle, and letehum. IIcCormick's mower was simply the reapere with platform removed and with the cutter set low. It did not operate well, however. Purviance's mower was also the reaper with platform removed and cutters lowered. The alteration was easily made and the machine operated quite woll, hut the commitere gave as its 


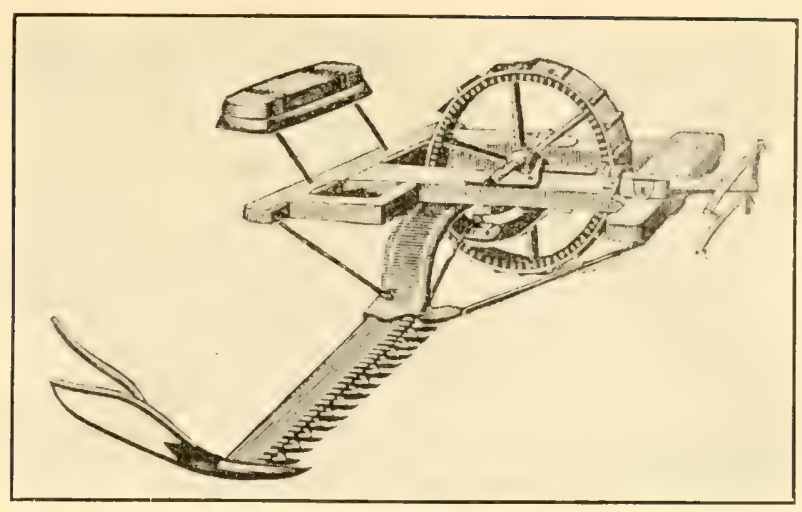

FIG. 1.--KETCHUM'S MOWER (1847).

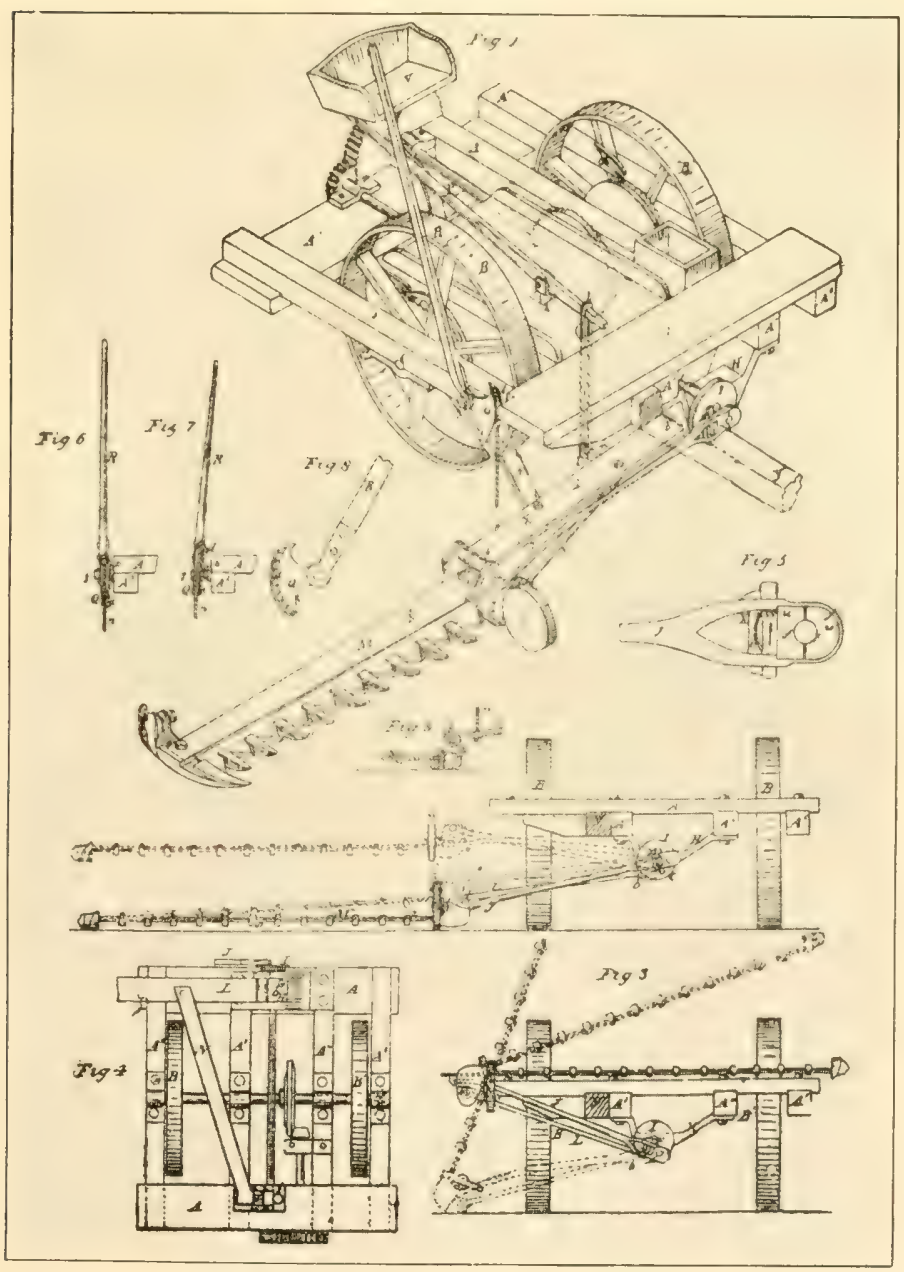

FIG. 2.-LEWIS MILLER'S MOWER (1858). 

opinion that combined machines were not so good as the separate types. This was undoubtedly correct, for the combined machines soon dropped out of riew on the appearance of the mower.

smith's combined machine was the third mower and reaper "xhibited at the above-named trial, but it failed to do good work. As to the mowers shown, II ussey"s was quite simple and operated well, but required three or four horses. Castle's, a creditable machine, with a reel and two series of knives, worked somewhat like Bell's old English type. The committere expessed itself as doubtful as to its operating when the knives became dull. Ketchum's was the simplest and most durable in construction and quite light in draft. It took the first prize, with the Hussey machine second. The report shows that Fetchum had a very practical machine in 15.52, with Husser a close second. ${ }^{1}$

Another trial at Geneva, N. Y., about the same time, shows Manny's, Kietchum's, Mc('ormick's, Murray's, Ruger's and I)anforl’s mathine's among the contestants. Manny's had a peculiarly constructed frame, and the knife could be lewulaterl while the machine was in motion. A reel was used, and the "utter sections showed the "arly reforts to

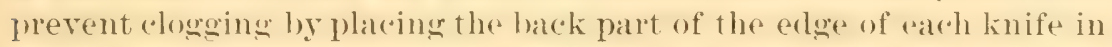
coutact with the guard, a modification of the Ifussey cutter. Retchum's had a simple compacet construction, with an iron show connect. ing the cutter bar with the rumning parts of the machine. It was the same style of machine as exhibiterl in the trial at sipringerelet. Ilccormick's machine had obtuse sickle-erleged secotions ami also the form of spear-shaperl finger's patented in $18+7$. Tho machine was too frail, and the knives could not staud the strain. Rugers resembled the old Bell machine, having the horses in the rear. It had a means of raising and lowering the cutters at will, hut som coased to operate. Danford's was also used as a reaper, and had a double crank with blates reciprocating past each other. IInssey, MroCormick, Cook, and Burrall exhibited combined machines.

At a trial in 1855 at Flushing, N. Y., there were five entries, Manny taking first and hetchum second prize. At a contest two reats later there were five entries-Wood's, Ketchum's, Allen's, Bartlow's, and Ilarmon's. Ketchum took first and Allen second prize. At the trial at Geneva in 1866, twenty different mowers were entered, so that it is seen that an immense amount of work had been done on this machine, and from the great number in competition it is sident that the successful mower had been developed. ${ }^{2}$

Returning to the history, however, wé find that in 1855 a patent was granted to Jonathan IIaines which was very important in the development of the flexible cutter har. It had two drive whesels and

${ }^{3}$ Report of Board Agriculture of Ohio, 1852, p. 120.

2Transactions New York Agricultural Society, 185:, 1855, 1857, 1860, 1866. $8910-N o, 103-02-1$ 
a cutter bar jointed to the main frame in such a mamer that it could be lifted over obstructions, and the tongue was rigidly fastened to the main frame.

()n .July 17, 1s56, a patent was granted to Cornelius Aultman and IAwis Millop containing principles that still exist in all successful mowers. The first patent claimed "comnecting the cutter bar to the mathine by the double-rule joint or the double-jointed coupling pin." It was reissuerl to cover an arrangement for holding up the bar while moving, and the combination of ratchet wheel, pawl, and spring. On May 4, 1858, Lewis Miller took out a patent on a mower that comhined the features of the former machine with some new principles. (I’l. IX, fig...) It contained all the elements of the successful modern two-whereal machine, and mower development since that time has been a perfecting of this type. This machine was built under the name of the "Buckere," and, with a substitution of metal for certain wooden parts, and certain other improvements, it is in use to-day. E. Ball, associated with this firm, also mate valuable improvements in mower's. In 1856 a patent was granted to A. Kirby, covering improvement made by him a few years previous, and his machines soon became popular. Ohers took up the manufacture of mowers at this early date, so that by lise the mower had become a thoroughly partical machine, and was being imploved hy various firms thoroughout the country. This improvement has gone on with the many makes of machines now in existence, and to-day we have various forms, from the single one-horse machine to the large two-horse type, with its long entter bar, running with as light a draft as the former clumsy machine did with a cut but half as wide. As a result of this development the amount of hay produced in the United States has increased enormously, and to-day it stands as one of the most important crops.

\section{REFERENCES TO LITERATURE.}

Ardrey, R. L. American Agricultural Implements. Chicago, 1894.

British Nanufacturing Industries. Agricultura Implements, p. 151.

Johnson, C. W. Nodern Agricultural Implements. London, 184i.

Memorial of Robert McCormick. Chicago, 1886, pp. 61.

()fficial Retrospective Exhibition of the Development of Harvesting Nachinery for the Paris Exposition of 1900, made by the Deering Harvester Company, pp. 125.

Slight, J., and Burn, R. S. Book of Farm Implements and Machines. Edinburgh, 1858.

Stabler, E. Overlooked Pages of Reaper History. Chicago, 1897, pp. 102.

Swift, R. B. Who Invented the Reaper? Chicago, 1897. pp. 54.

Thomas, J. J. Farm Implements and Their Construction and Use. New York, 1869.

Danberry's Roman Husbanclry. 
Depew, C. M. One Hundred Years of American Commerce. New York, 1895, Vol. II, p. 352. Chapter on Agricultural Machinery and Implements, E. M. Fowler.

Donaldson's British Agriculture, p. 238.

Doyle, M. Cyclopædia of Practical Husbandry and Rural Affairs in General. London, 1844, p. 49?.

Emerson, G. American Farmer's Encyclopædia. New Fork, 18.js.

Hoskrns, C. W. Short Inquiry into the History of Agriculture in Ancient. Medii:val, ancl Modern Times. London, 1849, pp. 160.

Johnson, C. W. Farmer's Encyclopædia and Dictionary of Rural Affairs. London, 1812; Philadelphia, 1851 (rev. by G. Emerson).

London, J. C. Encyclopædia of Agriculture. London, 1839, 4 ed., pp. 24, 5 , 372,420 .

Morton, J. C. Cyclopedia of Agriculture. Glasgow, 1851-1855, Vol. II, p. $i t 1$.

Periam, J. The American Encyclopredia of Agriculture. Chicago, 1881, p. 183.

Stephens, Henry. The Book of the Farm. Edinburgh and London, 18r1. "3 ed., Vol. II, p. 294.

Youat, W.. and Fream, W. Complete Grazier. Lon Ton, 1893, 1:3 ed., p. 738.

Wilson. J. II. Farmer's Dictionary. Edinburgh, 1851, Vol. II.

Wilson, J. II. Rural Encyclopedia. Edinburgh, 1851, Vol. IV, 1).2.

American Cyclopædia, 1875, Vol. XII, p. 16. Mowing and Reaping Machines.

American Mechanical Dictionary, Vol. III, p. 1888.

Appleton's Encyclopedia of Applied Mechanics, Vol, I, p. 1.).

Chambers's Encyclopedia. See article on Reaping.

Encyclopredia Britannica. See article on Agriculture.

International Cyclopæedia. New York, 1900, Vol. XII, 1. 458.

Johnson's Universal Encyclopiedia. New York, 1895, Vol. VII, p. 1\%.

Maison Domestique, Vol. I, p. 300.

National Encyclopædia, Vol. X, p. 83.

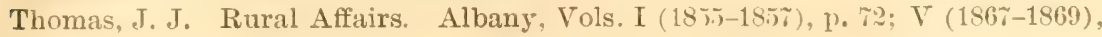
D. 103

Yomng, Arthur. Annals of Agriculture and Other Useful Arts. London, 8 (175\%), 1. 161 .

Eighth Census of the United States, 1860, Volume on Agriculture, p. 2).

Tenth Census of the United States, 1850, Vol. III, p. 1:31.

Report Board of Agricuiture or Ohio, 1852, p. 120.

Transactions Highland and Agricultural Society of Scotland, Edinburgh, Jannary $1863-1865$, p. 123.

Transactions New York Agricultural Society, 1852, 1855, 185\%, 1860, 1866.

Farm Implement News. Chicago, May 18, January 11, 1900; July 6 and $2 \tau$, A ugust $3,10,17,24$, and 31 , and September 7 and $21,189 \%$.

Gardener's Magazine. London, 5 (1829), p. 600; 6 (1830), p. 295.

New York Tribune, Half Century of Agriculture. December 22, 189\%.

North British Agriculturist. Edinburgh. July 19, 1893.

Journal of Agriculture. Edinburgh and London, 1851-53, pp. 478, 654; 185\%-55, pp. $175,185,541,611 ; 1855-57$, pp. $65,14 \tau ; 185 \tau-59$, p. 61.

Scientific American. New York, December 16 and 23, 1854; July 25, 1896; February 3, 1900. 





\section{LIBRARY OF CONGRESS}

|||||||| ||| |||||||||||||||||||||||||||||||||

||||||||||||||||||||||||||||||||||||||||||||||||||

\section{प002758570A}

